Additional Perspectives articles for Influenza: The Cutting Edge book collection are available at http://perspectivesinmedicine.cshlp.org/cgi/collection/influenza_the_cutting_edge.

\title{
Influenza in High-Risk Hosts-Lessons Learned from Animal Models
}

\author{
Rebekah Honce, ${ }^{1,2}$ Nicholas Wohlgemuth, ${ }^{1}$ Victoria A. Meliopoulos, ${ }^{1}$ Kirsty R. Short, ${ }^{3}$ \\ and Stacey Schultz-Cherry ${ }^{1}$ \\ ${ }^{1}$ Department of Infectious Diseases, St. Jude Children's Research Hospital, Memphis, Tennessee \\ 38105-3678, USA \\ ${ }^{2}$ Integrated Program in Biomedical Sciences, Department of Microbiology, Immunology, and Biochemistry, \\ University of Tennessee Health Science Center, Memphis, Tennessee 38163, USA \\ ${ }^{3}$ School of Chemistry and Molecular Biosciences, The University of Queensland, St Lucia, Brisbane, \\ Queensland 4072, Australia \\ Correspondence: stacey.schultz-cherry@stjude.org
}

Factoring significantly into the global burden of influenza disease are high-risk populations that suffer the bulk of infections. Classically, the very young, very old, and pregnant women have been identified as high-risk populations; however, recent research has uncovered several other conditions that contribute to severe infection. By using varied animal models, researchers have identified molecular mechanisms underpinning the increased likelihood for infection due to obesity and malnourishment, as well as insight into the role sex hormones play in antiviral immunity in males, in females, and across the life span. Additionally, novel comorbidity models have helped elucidate the role of chronic infectious and genetic diseases in influenza virus pathogenesis. Animal models play a vital role in understanding the contribution of host factors to influenza severity and immunity. An in-depth understanding of these host factors represents an important step in reducing the burden of influenza among the growing number of people living with one or more chronic medical conditions.

nfluenza represents a significant burden for global public health. Worldwide, millions of cases of influenza are recorded per year, resulting in estimates of up to 600,000 deaths (Thompson et al. 2009; Nair et al. 2011; Lee et al. 2018). Most cases are represented by individuals with one or more underlying host susceptibility factors. Comorbidities, sex, and age not only impact the host but can also impact the virus itself, as they were found to be associated with increase in single-nucleotide polymor- phisms (SNPs) in the influenza genome (Fig. 1) (Nelson et al. 2001; Engels et al. 2017; Zhang et al. 2017). To understand increased pathogenesis in high-risk populations, it is necessary to develop accurate animal models to investigate viral pathogenesis and immunity.

\section{OBESITY}

Obese individuals are at high risk for severe influenza infection and account for most influ-

Editors: Gabriele Neumann and Yoshihiro Kawaoka

Additional Perspectives on Influenza: The Cutting Edge available at www.perspectivesinmedicine.org

Copyright (C) 2020 Cold Spring Harbor Laboratory Press; all rights reserved; doi: 10.1101/cshperspect.a038604

Cite this article as Cold Spring Harb Perspect Med 2020;10:a038604 
R. Honce et al.
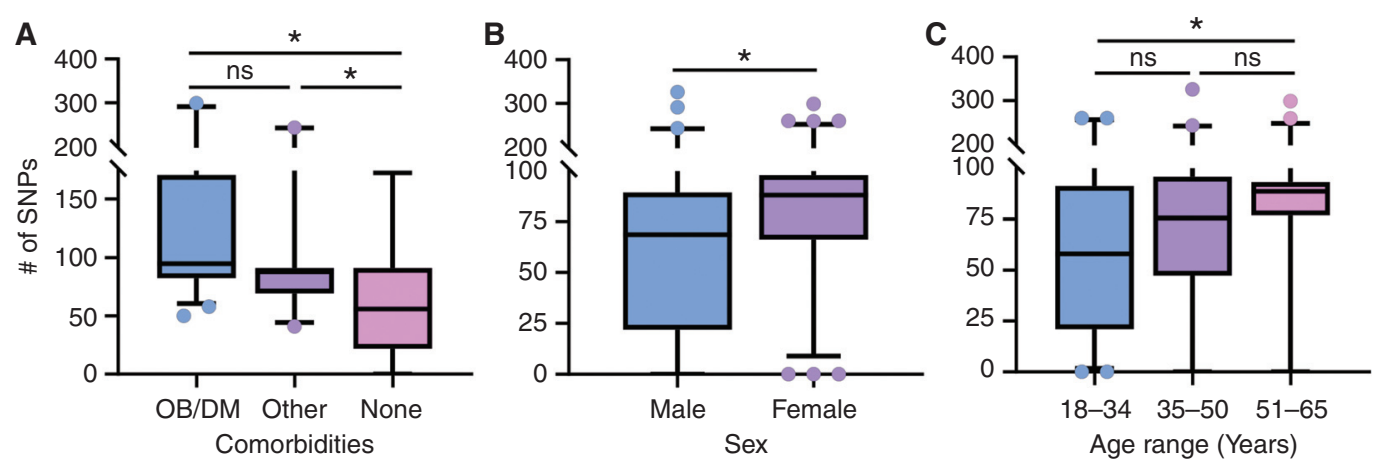

Figure 1. Increased diversity in viruses derived from high-risk hosts. Using the influenza research database, human surveillance influenza A viral samples with clinical metadata were pooled to look at single-nucleotide polymorphisms (SNPs) in various high-risk groups. The same data set was stratified based on $(A)$ comorbid state of obesity or diabetes mellitus, other comorbidity, or healthy adult with no listed comorbidities, $(B)$ sex, and $(C)$ age range on presentation of symptoms of 18-34, 35-50, or 51-65. Number of SNPs for each gene segment was summed and plotted using box-and-whisker plots ranging from the 5th to 95th percentile with data outside the range represented by data points. Data were analyzed first for normality using the Kolmogorov-Smirnov test, and then for differences in SNPs using a Kruskal-Wallis test $(A, C)$ to compare more than two groups and a MannWhitney test $(B)$ to compare two groups. $\left({ }^{*}\right) P<0.05$. Database accessed on 30-July-2019.

enza-related hospitalizations (Milner and Beck 2012). To better understand this increased pathogenesis, most influenza obesity studies to date have been performed in mouse models-specifically, genetically obese mouse strains such as $\mathrm{ob} / \mathrm{ob}(\mathrm{OB})$ and $\mathrm{db} / \mathrm{db}$, achieved by knocking out the leptin gene or the leptin receptor, respectively (Lutz and Woods 2012), and diet-induced obese (DIO) mice, which are thought to better mimic obesity in the human population. DIO mice are fed diets consisting of high-fat (ranging from $40 \%$ to $60 \%$ calories from fat) or a so-called Western diet with variable composition (Table 1) (Lutz and Woods 2012; Zeeni et al. 2015). These high-fat, calorically dense diets result in weight gain, glucose intolerance, and reduced sensitivity to leptin and insulin (Campfield et al. 1995).

Most murine studies show that obesity increases morbidity and mortality during influenza infection, consistent with clinical observations (Milner and Beck 2012). On infection with influenza virus, both OB and DIO mice develop severe pathology, increased viral spread, decreased pulmonary function, and impaired viral clearance (Kim et al. 2012b; Zhang et al. 2013; Radigan et al. 2014; Moorthy et al. 2016; Karlsson et al. 2017a). A major complication of influenza infection, especially in obese populations, is the development of secondary bacterial infections (Diavatopoulos et al. 2010). Obese mice are at greater risk of acquiring secondary infections post-influenza challenge (Karlsson et al. 2017a). Conversely, other studies reported no differences in pathology between lean and obese, although they did report mice fed highfat diets (HFDs) have increased oxidative stress and generation of neutrophil extracellular traps, both of which result in damage to the surrounding tissue (Moorthy et al. 2016).

Besides increased pathology, obese mice mount a poor innate immune response to infection (for review, see Honce and Schultz-Cherry 2019). The baseline obesogenic lung consists of increased expression of proinflammatory cytokines and chemokines (Kim et al. 2012b) resulting in an increased influx of inflammatory cells after infection (Namkoong et al. 2019). Despite the increased inflammation, obese mice have increased expression of suppressors of cytokine signaling (SOCS1 and SOCS3) mRNA in the lung leading to decreased type I interferon (IFN) (Radigan et al. 2014). On infection, IFN $-\alpha$ and IFN $-\beta$ responses are delayed, along with IL- 6 and tumor necrosis factor (TNF)- $\alpha$ production (Smith et al. 2007; Karlsson et al. 
Influenza in High-Risk Hosts

Table 1. Animal models of obesity and outcome of experimental influenza virus infection

\begin{tabular}{|c|c|c|c|c|c|}
\hline Model & Genetics & Weight & Diet & Outcome of infection & References \\
\hline $\begin{array}{l}\text { Genetic } \\
\text { leptin } \\
\text { knockout } \\
\text { (ob/ob) }\end{array}$ & $\begin{array}{l}\text { Spontaneous } \\
\text { recessive, } \\
\text { homozygous } \\
\text { Lep }^{o b} \text { nonsense } \\
\text { mutation }\end{array}$ & $45 \mathrm{~g}$ & $\begin{array}{l}\text { Normal chow; } \\
\text { hyperphagic due } \\
\text { to loss of } \\
\text { appetite control } \\
\text { and satiety }\end{array}$ & $\begin{array}{l}\text { Impaired viral } \\
\text { clearance, } \\
\text { increased risk of } \\
\text { secondary } \\
\text { infections, poor } \\
\text { wound repair, and } \\
\text { diminished } \\
\text { memory responses }\end{array}$ & $\begin{array}{l}\text { Campfield et al. 1995; } \\
\text { Lutz and Woods } \\
\text { 2012; Karlsson } \\
\text { et al. 2017a; } \\
\text { Meliopoulos et al. } \\
2019\end{array}$ \\
\hline $\begin{array}{l}\text { Genetic } \\
\text { leptin } \\
\text { receptor } \\
\text { knockout } \\
(\mathrm{db} / \mathrm{db})\end{array}$ & $\begin{array}{l}\text { Spontaneous } \\
\text { mutant in } \\
\text { Lepr }^{d b} \text { allele } \\
\text { causing } \\
\text { abnormal } \\
\text { splicing }\end{array}$ & $40 \mathrm{~g}$ & $\begin{array}{l}\text { Normal chow; } \\
\text { hyperphagic due } \\
\text { to loss of leptin } \\
\text { receptor signal } \\
\text { transduction }\end{array}$ & $\begin{array}{l}\text { Reduced viral } \\
\text { clearance, } \\
\text { impaired adaptive } \\
\text { immunity, and } \\
\text { increased lung } \\
\text { pathology }\end{array}$ & $\begin{array}{l}\text { Lutz and Woods } \\
\text { 2012; Radigan } \\
\text { et al. } 2014\end{array}$ \\
\hline $\begin{array}{l}\text { Diet- } \\
\text { induced } \\
\text { obesity } \\
\text { (DIO) }\end{array}$ & $\begin{array}{l}\text { Some strains more } \\
\text { susceptible } \\
\text { than others }\end{array}$ & $35 \mathrm{~g}$ & $\begin{array}{l}\text { High-fat, Western, } \\
\text { or "cafeteria" } \\
\text { diet }\end{array}$ & $\begin{array}{l}\text { Mirrors genetically } \\
\text { obese models, but } \\
\text { generally moderate } \\
\text { phenotypes } \\
\text { between } \\
\text { genetically obese } \\
\text { and control } \\
\text { models }\end{array}$ & $\begin{array}{l}\text { Campfield et al. 1995; } \\
\text { Smith et al. 2007; } \\
\text { Lutz and Woods } \\
\text { 2012; O’Brien et al. } \\
\text { 2012; Zeeni et al. } \\
2015\end{array}$ \\
\hline Control & $\begin{array}{l}\text { Any matched } \\
\text { genetic } \\
\text { background }\end{array}$ & $25 \mathrm{~g}$ & $\begin{array}{l}\text { Either low-fat diet } \\
\text { or regular chow; } \\
\text { diet choice may } \\
\text { alter results }\end{array}$ & $\begin{array}{l}\text { Controlled viral } \\
\text { spread and } \\
\text { replication, } \\
\text { reduced lung } \\
\text { pathology, } \\
\text { improved wound } \\
\text { repair, and robust } \\
\text { antigenic memory }\end{array}$ & $\begin{array}{l}\text { Lutz and Woods } \\
\text { 2012; Zeeni et al. } \\
2015\end{array}$ \\
\hline
\end{tabular}

Adapted from data in Honce and Schultz-Cherry (2019).

2010; Lutz and Woods 2012). However, later in infection, DIO mice have increased IL-6 levels versus lean mice (Namkoong et al. 2019). Macrophages, one of the first innate immune cells to sense infection and initiate a response, are functionally impaired in obese hosts. Alveolar macrophages taken from DIO mice and infected ex vivo have suppressed IFN- $\alpha$, IFN- $\beta$, and other cytokines compared with lean controls, suggesting dampened macrophage function in DIO mice contributes to poor outcomes (Cho et al. 2016; Namkoong et al. 2019).

The adaptive immune system is also affected by obesity. Pulmonary CD $4^{+} \mathrm{T}$ cell numbers are reduced in DIO and $\mathrm{OB}$ mice (Milner et al. 2015). Regulatory $\mathrm{T}$ cells are reduced in DIO and $\mathrm{OB}$ mice and are $40 \%$ less suppressive than those of lean mice (Milner et al. 2013, 2015). Weight loss does not improve memory T-cell function in DIO mice (Rebeles et al. 2019), implying that obesity might continue to have an impact even after an individual loses weight. Humoral responses are also altered. DIO mice have higher B-cell IgM and IgG in unstimulated B cells, but decreased expression of cytokines and early commitment markers such as IL-7, IL-7RA, and STAT5 (Kosaraju et al. 2017). Not only are B-cell frequencies lowered, but DIO mice have diminished antibody titers attributed to reduced plasma levels of docosahexaenoic acid (DHA) (Kosaraju et al. 2017). Many studies have shown differ- 
R. Honce et al.

ences in inflammation and immune cell populations-both innate and adaptive-are more pronounced in the genetically obese models compared with DIO mice, drastically affecting the immune response to influenza (O'Brien et al. 2012).

An altered pulmonary microenvironment also contributes to increased pathogenesis and impaired immune response. Prostaglandin $\mathrm{E}_{2}$, a lipid immune mediator, is higher in DIO mice and mediates decreased expression of IFN- $\alpha$, IFN- $\beta$, and certain cytokines (Zhang et al. $2019 b$ ). In addition, during infection, lipid metabolism in DIO mice is up-regulated, including fatty acids and phospholipids (Milner et al. 2015). Although the exact impact of increased lipid metabolism on pathogenesis is unknown, it is speculated that the altered cellular metabolism of obese mice inhibits efficient lung repair after infection (O'Brien et al. 2012; Milner et al. 2015). Mechanisms of pulmonary homeostasis are also altered by the obesogenic state. Recent studies show that the $\beta 6$ integrin contributes to increased pathology during influenza infection in mice by suppressing type I IFNs (Meliopoulos et al. 2016), and that $\beta 6$ integrin is expressed at much higher levels in genetically obese mice (Meliopoulos et al. 2019). Knocking out $\beta 6$ integrin increases type I IFN signaling and improves macrophage functionality, resulting in controlled viral spread and protection from severe influenza infection (Meliopoulos et al. 2016, 2019). Obese mice have increased expression of platelet-activating factor receptor (PAFR) in the lung, which is associated with increased severity of secondary bacterial infection (Ghoneim et al. 2013; Metzger and Sun 2013; Karlsson et al. 2016).

Although the mouse model provides valuable information regarding the influence of obesity during influenza infection, ferrets remain the gold-standard model for human influenza infection. Unlike mice, ferrets are susceptible to human influenza viruses without the need for prior adaptation and have a distribution of sialic acid residues within the respiratory tract that mirrors that of humans (Robinson et al. 1986; Johnson-Delaney and Orosz 2011). Ferret studies are limited by the lack of available ferret reagents and currently focus on viral pathogenesis and viral transmission. To address this, the National Institute of Allergy and Infectious Diseases (NIAID)-funded Centers for Excellence in Influenza Research and Surveillance has undertaken an initiative to develop ferret immune reagents and antibodies (Albrecht et al. 2018). An obese ferret model is thus currently under development and has the potential to answer many questions about obesity and influenza.

Overwhelmingly, data generated from studies using DIO and genetically obese mouse models suggests increased immunopathology, decreased or delayed immune response, and altered pulmonary microenvironment all contribute to the increased morbidity and mortality seen in obese individuals. Although differences between studies have been noted, this is most likely attributed to differences between obesity models and diets. Even diets of similar composition can be obtained from different vendors with major or minor differences between formulations. Therefore, caution must be taken when extrapolating murine results to studies of human obesity and influenza.

\section{MALNOURISHMENT}

Malnourishment is also a risk factor for increased influenza susceptibility and morbidity. Several studies have found that vitamin A and D deficiencies affect the immune response to influenza virus (Stephensen et al. 1993; Surman et al. 2016; Penkert et al. 2017). Mice deficient in vitamin $A$, vitamin $\mathrm{D}$, or both have decreased mucosal antibody response in the nasal-associated lymphoid tissue and lung; supplementation with vitamin $\mathrm{A}$ and/or D was sufficient to restore the antibody response (Surman et al. 2017). Vitamin A- and vitamin D-deficient mice, in addition to decreased overall numbers of $\mathrm{CD}^{+} \mathrm{T}$ cells, have decreased virus-specific CD103 ${ }^{\text {hi }} \mathrm{T}$ cells, thought to inhibit recruitment of virus-specific $\mathrm{T}$ cells to the airway (Surman et al. 2017). Low vitamin C levels also contribute to poor infection outcome, as $\mathrm{Gulo}^{-/-}$mice, which are unable to survive without vitamin $\mathrm{C}$ supplementation, show increased lung pathology and decreased MCP-1, RANTES, and IL-12 
during influenza infection (Li et al. 2006). Selenium deficiency increases influenza-associated lung lesions, as well as promotes higher mutation rates in the M1 protein (Beck 2001; Beck et al. 2001; Nelson et al. 2001).

Protein deprivation also increases severity of disease. Mice fed inadequate amounts of protein show increased viremia and delayed viral clearance compared to controls (Pollett et al. 1979; Taylor et al. 2013). This may reflect the altered immune response of these mice, as protein-deprived mice have fewer natural killer (NK) cells, leading to decreased levels of IFN- $\gamma$ as well as reductions in $\mathrm{B}$ cells, $\mathrm{T}$ cells, and total numbers of leukocytes during influenza infection (Ritz et al. 2008; Taylor et al. 2013). In addition, protein deprivation results in increased levels of lung neutrophils associated with immunopathology and lower serum hemagglutination inhibition titers (Taylor et al. 2013), suggesting reduced protein intake compromises both the innate and adaptive responses.

\section{SEX DIFFERENCES}

Hormonal variations between sexes have a marked impact on antiviral responses (Klein et al. 2010; Vom Steeg and Klein 2019). Although influenza titers are largely similar between sexes, experimental influenza infection of male and female mice reveals a greater induction of proinflammatory cytokines and increased morbidity in female mice, whereas males show less production of humoral immune responses (Lorenzo et al. 2011; Robinson et al. 2011; Klein et al. 2012; Vom Steeg and Klein 2017). This differential response to influenza infection is mitigated after gonadectomy, suggesting a role for sex hormones in the pathogenesis of influenza (Robinson et al. 2011).

$17 \beta$-estradiol (E2) alleviates pulmonary inflammatory responses and promotes an antiviral state by recruiting neutrophils and influenzaspecific $\mathrm{CD}^{+} \mathrm{T}$ cells to the lungs; however, in females, low levels of $\mathrm{E} 2$ promote inflammation and immunopathology (Robinson et al. 2011, 2014; Klein et al. 2012; Davis et al. 2017). Exogenous application of $\mathrm{E} 2$ protects females from severe influenza by increasing pulmonary mi- gration of neutrophils and enhancing $\mathrm{CD} 8^{+}$ T-cell responses (Robinson et al. 2014). Conversely, during pregnancy, high levels of E2 may attenuate the antiviral response, leading to increased morbidity after influenza virus infection (Pazos et al. 2012). Estriol (E3), another endogenous estrogen, protects against pulmonary inflammation but does not reduce lung viral titers (Vermillion et al. 2018b). These findings were confirmed in vitro: Treatment of female-derived, but not male-derived, human nasal epithelial cell cultures with estrogenic compounds improved cellular response to infection (Peretz et al. 2016).

Progesterone (P4) has both detrimental and beneficial roles for the host during infection. P4 treatment of female mice promotes pulmonary up-regulation of amphiregulin, fast-tracking lung repair and recovery (Hall et al. 2016). In contrast, ovariectomized female mice exogenously treated with $\mathrm{P} 4$ have increased morbidity following influenza virus infection, which is also noted in pregnant mice during peak $\mathrm{P} 4$ levels (Davis et al. 2017). Hormonal contraceptives containing $\mathrm{P} 4$ reduce memory responses to heterotypic influenza challenges through decreasing the activity of memory $\mathrm{CD} 8^{+} \mathrm{T}$ cells (Hall et al. 2017).

Testosterone levels can also impact the response to influenza infection, and testosterone decline over the life span contributes to increased severity in the elderly (Vom Steeg et al. 2016; Vom Steeg and Klein 2019). As is seen with estrogens and progesterone, testosterone levels do not alter viral load but rather impact immune responses (Vom Steeg et al. 2016). Castrated young and intact aged male mice suffer increased pulmonary pathology and edema upon infection because of low testosterone levels (Vom Steeg et al. 2016). Testosterone also plays a role in the recovery and remodeling stage of infection. Male mice show greater production of amphiregulin than female mice with responses sensitive to exogenous testosterone treatment (Vermillion et al. 2018c).

Hormonal fluctuations across the life span impact susceptibility to influenza differently in males and females; these differences are highlighted during aging and pregnancy. Prepuber- 
R. Honce et al.

tal and elderly males have a higher likelihood of severe influenza infection compared with higher susceptibility in females of reproductive age as discussed further below (Jensen-Fangel et al. 2004; Vom Steeg and Klein 2019). Further, puberty onset may increase disease severity in males and females, as increased production of estrogens exacerbate mortality on infection. Low estrogen levels in prepubertal children-especially females-are protective against severe influenza infection (Suber and Kobzik 2017). Testosterone decline over the life span increases susceptibility to influenza in aging males, and the dynamic interaction between aging and sex hormones impacts influenza pathogenesis as well as host responses to infection and vaccination, as discussed below (Vom Steeg et al. 2016; Potluri et al. 2019).

\section{PREGNANCY}

Following the 1918 and $2009 \mathrm{H} 1 \mathrm{~N} 1$ pandemics, studies found pregnant hosts had a greater likelihood of hospitalization after influenza infection versus nonpregnant women (Woolston and Conley 1918; Titus and Jamison 1919; Siston et al. 2010). Strikingly, pregnant women account for only $1 \%$ of the general population, yet experience an excessive rate of mortality of $5 \%$ on influenza virus infection (Centers for Disease Control and Prevention 2010). Interactions between hormones and immune mediators in systemic circulation and at the mother-fetal interface alter influenza pathogenesis in the pregnant host, as well as contribute to sex-based differences in the response to infection (Irving et al. 2000; Raj et al. 2014; van Riel et al. 2016; Littauer and Skountzou 2018). Other comorbidities, including stress, depression, body mass index, aging, puberty, and exercise state, contribute to poor infection responses and can compound morbidity in pregnant hosts (Christian et al. 2010; Avitsur et al. 2011; Soydinc et al. 2012; Christian 2014; Ingersoll 2017; Vom Steeg and Klein 2017).

Pregnant mouse models, including syngenic mating between like strains of mice and allogenic mating between different strains of mice, yield insights into the altered influenza pathogenesis in pregnant hosts. Reduced viral clearance and eightfold higher viral titers characterize the lungs of syngeneic and allogenic pregnant mice infected during mid-gestation, with allogenic-mated mice showing more severe disease caused by fetal tolerance (van Riel et al. 2016; Engels et al. 2017; Littauer et al. 2017). Increased disease severity is not strain-specific; increased viral loads are observed with influenza B-infected pregnant mice as well (Kim et al. 2014). Higher viral loads in pregnant mice contribute to increased lung pathology, severe pneumonitis, lung edema, cytokine storm, and reduced epithelial regeneration post-acute lung injury (Chan et al. 2010; Gu et al. 2011; Marcelin et al. 2011; Engels et al. 2017; Vermillion et al. 2018a). The trend of increasing maternal mortality as pregnancy advances has been recapitulated in murine models with infection during the third gestational week inducing three times the mortality versus infection in the first gestational week (Williams and Mackenzie 1977; Siston et al. 2010).

Reduced antiviral responses upon influenza virus infection may promote immune tolerance to the fetus; however, this can lead to a detrimental outcome for maternal and fetal health. Reduced type I and III IFN responses are seen in pregnant female-derived human peripheral blood mononuclear cells (PBMCs) and in allogenic and syngenic mated pregnant mice (Forbes et al. 2012; Engels et al. 2017; Littauer et al. 2017). The predominate source of type I IFNs following infection are circulating plasmacytoid dendritic cells ( $\mathrm{pDCs}$ ), a cell type that shows reduction in numbers but heightened Toll-like receptor (TLR) expression during pregnancy (Cordeau et al. 2012; Vanders et al. 2013; Koga et al. 2014; Le Gars et al. 2016). Upon infection, infiltrating $\mathrm{pDCs}$ in the maternal decidua-which itself expresses several TLRs-during pregnancy may contribute to preterm labor, preeclampsia, and increased maternal morbidity detected in rat and mouse pregnancy models (Beijar et al. 2006; Ilievski et al. 2007; Koga et al. 2014).

Increased expression of pro-inflammatory cytokines IL-1 $\alpha$, IL-6, IL-12, TNF- $\alpha$, G-CSF, RANTES, and MCP-1, increased immunosuppressive cytokines IL-10 and IFN- $\gamma$, and type I and III IFNs reduction together alter the cellular 
microenvironment of the maternal lung and promote severe immunopathology-alterations that are compounded as pregnancy advances (Gonzalez et al. 2009; Chan et al. 2010; Kraus et al. 2010; Marcelin et al. 2011; Forbes et al. 2012; Kim et al. 2012a; Zheng et al. 2012; Vanders et al. 2013). Pregnancy in the ferret model supports these findings, as increased inflammatory cytokines in the lungs lead to cytokine imbalance and elevated viral replication compared with nonpregnant, influenza virus-infected controls (Yoon et al. 2018).

Some reports suggest no differences or even improvements in antibody levels or T-cell numbers and function in influenza virus infected pregnant animal models (Norton et al. 2010; Marcelin et al. 2011; Kay et al. 2014); however, the majority note impairments in adaptive effector function and memory due to the pregnant state. There is a dearth of knowledge on alterations to antibody-mediated immunity and $\mathrm{B}$ cells in influenza infection during pregnancy in animal models and human cohorts. Influenza infection in the pregnant ferret model does show reduced IgG-specific B-cell responses after experimental infection, although it remains to be determined if this occurs during natural infection in humans (Yoon et al. 2018). Interestingly, the complement pathway components $\mathrm{C} 3, \mathrm{C} 3 \mathrm{a}$, and $\mathrm{C} 4$ show diminished antibody-dependent neutralization of influenza in pregnant African green monkeys (Mayer and Parks 2014).

$\mathrm{CD}^{+}$and $\mathrm{CD}^{+} \mathrm{T}$ cells are reduced in numbers and have heightened exhaustion in pregnant women infected with H1N1 (Vanders et al. 2013). In mice, increased programmed cell death (PD)-1 expression on paternal antigen-specific $\mathrm{T}$ cells promote fetal tolerance through apoptosis of potentially cytotoxic, fetal-targeted cells. Conversely, up-regulation of $\mathrm{PD}-1$ during pregnancy is mirrored during influenza infection, and blocking the PD-1 ligand improves maternal immunity (Taglauer et al. 2009; Vanders et al. 2015). There is also evidence that pregnancy biases toward a Th2-dominated immunity and results in the reduction of $\mathrm{CD}^{+} \mathrm{T}$ cells on influenza infection in mouse, rat, and ferret models (Gu et al. 2011; Vanders et al. 2015; Yoon et al. 2018).
The fetus can experience adverse outcomes on influenza infection of the mother. Severe infections are associated with preterm delivery, increased rates of stillbirth, and low birth weight (Kim et al. 2014; Härtel et al. 2016; Oboho et al. 2016; Fell et al. 2017; Littauer et al. 2017). Influenza can infect fetal-related tissues, with infections of the maternal decidua of the greatest likelihood to support active viral replication (Takeyama 1966; Rosztoczy et al. 1975; McGregor et al. 1984; Uchide et al. 2006). Infection of the fetoplacental tissues induces placental inflammation may precede influenza-induced abortion, as has been shown in human and simian tissues and in murine models (Uchide et al. 2002; Christiaens et al. 2008; Xu et al. 2011; Kim et al. 2012a). Transmittance of influenza infection to the fetus may be a maternal survival strategy, as vertical transmission of highly pathogenic avian influenza H5N1 to the fetus induced preterm delivery or abortion but partly evacuated the virus from the pregnant dam (Xu et al. 2011).

Fewer studies have used the ferret model. An investigation into influenza virus dynamics in the mother-infant dyad using influenza-infected neonatal ferrets found influenza transmission to maternal lung and mammary gland tissue results in cessation of milk production and maternal mortality (Paquette et al. 2015). The converse condition of maternal infection via mammary gland inoculation resulted in infant infection and mortality via breastfeeding, findings that were recapitulated in replication competent primary human breast cells (Paquette et al. 2015).

\section{AGING}

Classically, the age groups at highest risk for severe influenza disease are the young and the elderly (Kondrich and Rosenthal 2017; Talbot 2017). This leads to a "U-shaped" age-specific mortality curve with high mortality in young and old with young adults and middle-aged individuals having relatively low mortality (Fig. 2) (Dauer and Serfling 1961; Glezen 1996). Prepubescent children, especially children with comorbidities or children $<2 \mathrm{yr}$ of age, are at an 


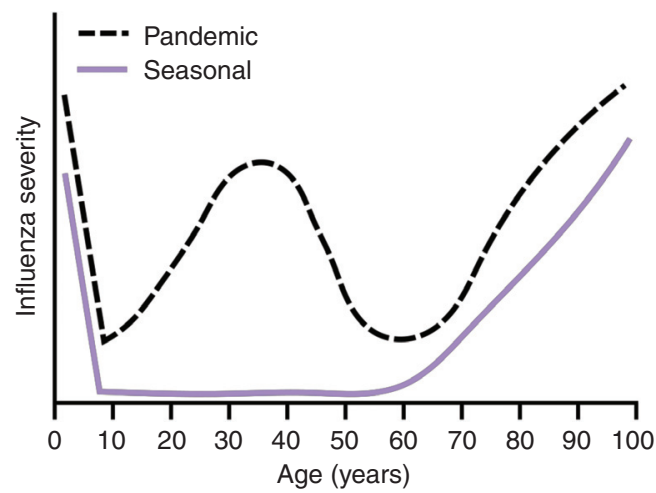

Figure 2. Differential severity of pandemic and seasonal influenza viruses by age. Seasonal influenza viruses cause a "U-shaped" age-specific mortality curve with the young and old susceptible to severe influenza virus disease. Pandemic influenza viruses instead cause a "W-shaped" age-specific mortality curve with the young, old, and middle-aged having peaks in influenza virus disease severity.

increased risk for severe complications following influenza virus infection (Nair et al. 2011; Lafond et al. 2016; Guo et al. 2018). In part, the high risk of severe disease in children is thought to be caused by a lack of enough preexisting immunity, resulting in high infection rates (Ruf and Knuf 2014). The relative lack of sex hormones in prepubescent individuals also makes them more susceptible to severe influenza disease, as discussed above (Vom Steeg and Klein 2019). Work in animals has shown that prepubescent mice are similarly susceptible to severe disease following influenza virus infection (Yasui et al. 2004; Sun et al. 2011). However, young ferrets have decreased fever and weight loss following influenza virus infection (Huang et al. 2012), perhaps because of the differences between the animal models (Thangavel and Bouvier 2014).

At the other end of the "U-shaped" age-specific mortality curve, older individuals ( $>65 \mathrm{yr}$ of age) also have a higher risk of severe influenza virus disease (Fig. 2). In otherwise healthy, elderly adults, $67 \%$ percent of influenza virus-infected individuals become housebound and 25\% become bedbound (Falsey et al. 2005). Despite numerous exposures to influenza virus via infection and vaccination, morbidity and mortality increase with age in the elderly, likely because of immunosenescence and increasing incidence of comorbidities (Talbot 2017). Older mice infected with influenza virus have increased morbidity and mortality associated with increased virus replication, decreased naive $\mathrm{T}$-cell receptor repertoire, and delayed resolution of inflammation (Yager et al. 2008; Gil et al. 2015; Vom Steeg et al. 2016; Nikolich-Žugich 2018; Vom Steeg and Klein 2019). Furthermore, immunosenescence during influenza virus infection is associated with lung macrophage alterations, resulting in decreased phagocytosis and increased pulmonary fibrosis (Samy and Lim 2015; Wong et al. 2017). Immunosenescence is thought to be related to reproductive senescence. Sex hormones decrease with age in older individuals, and, as described above, are important mediators of protection against influenza virus (Robinson et al. 2011, 2014; Hall et al. 2016; Peretz et al. 2016; Vom Steeg et al. 2016; Guo et al. 2018).

In contrast to what is seen during seasonal influenza virus epidemics, there can be an increase in influenza disease severity among young adults and middle-aged individuals during influenza virus pandemics, resulting in a "W-shaped" age-specific mortality curve (Fig. 2). The 1918 pandemic induced high morbidity among all ages, but young adults had a disproportionately higher rate of mortality (Morens et al. 2008; Walters et al. 2016; Taubenberger et al. 2019) potentially attributed to the virus's ability to induce a dysregulated pro-inflammatory immune response, as shown in mice, ferrets, and cynomolgus macaques (Kobasa et al. 2004, 2007; Kash et al. 2006; Memoli et al. 2009; de Wit et al. 2018; Short et al. 2018). During the influenza virus seasons immediately after pandemics, there tends to be a flattening of the young adult hump in the age-specific mortality curve back into the "U-shape" (Fig. 2; Simonsen et al. 1998; Taubenberger et al. 2019). This likely indicates the selective acquisition of protective immunity among this age group (Simonsen et al. 1998). Older adults, especially those aged 30-60, fared better than expected during such an intense pandemic, likely owning to previous exposure to $\mathrm{H} 1$ - and $\mathrm{N} 1$-containing viruses that were circulating in the 19th century (Luk et al. 
2001; Viboud et al. 2013; Short et al. 2018; Taubenberger et al. 2019).

Another possible reason for increased susceptibility to influenza virus infection during middle and old age is original antigenic sin (OAS), also known as immune imprinting. First observed in the 1960s, OAS describes the process by which the first antigenic variant of influenza virus that an individual is exposed to can shape subsequent humoral responses to influenza virus infection or vaccination (Francis 1960; Zhang et al. 2019a). Subsequent exposures to novel strains boost cross-reactive antibodies, resulting in strong humoral immunity to only a few antigens of the original strain, regardless of their effectiveness at neutralizing currently circulating strains. Therefore, after years of influenza virus evolution, novel drift variants can emerge and escape the highly specific humoral responses that have been selected, resulting in adults potentially becoming more susceptible to seasonal influenza viruses. However, it should be noted that in some individuals, OAS can lead to the boosting of antibodies that target conserved, broadly neutralizing epitopes like those in the HA stalk protein. Although it is likely impossible to model the complex influenza immune history of an adult, mice and ferret models have shown that sequential immunization can concentrate HA stalk antibodies (Krammer et al. 2013, 2014; Margine et al. 2013; Nachbagauer et al. 2016).

\section{OTHER HIGH-RISK STATES}

\section{Allergic Airway and Asthma}

Clinical observations have shown that asthmatics and allergy sufferers have increased morbidity on influenza infection. Murine models of allergic asthma differ in the allergen triggerincluding ovalbumin, house dust mite, and fungal allergens-and severity of resulting allergic disease (Nials and Uddin 2008; Gold et al. 2015; Debeuf et al. 2016). Allergic mice show prior airway inflammation increases resistance to subsequent influenza infection-a phenomenon opposite of what is seen in epidemiological studies of human asthmatics (Ishikawa et al. 2012;
Samarasinghe et al. 2014; Furuya et al. 2015; Kawaguchi et al. 2017). This protection is conferred to secondary bacterial coinfections caused by heightened TGF- $\beta$ expression in asthmatic mice suppressing IFN- $\gamma$ and promoting induction of robust antibacterial responses (Roberts et al. 2019). The protective effects of the allergic airway ameliorate damage to the epithelial surface, increase mucus production, and reduce weight loss on influenza infection during the peak allergic response and heightens eosinophilic responses capable of viral clearance (Samarasinghe et al. 2014, 2017). Alternatively, others have suggested enhanced levels of insulin-like growth factor-1 or NK cell activity in asthmatic mice may mediate protection from influenza (Ishikawa et al. 2012; Samarasinghe et al. 2014).

Asthma-induced protection is largely temporal. Influenza infection during remodeling after an allergic attack is detrimental; increased IFN levels result in immunopathology (Samarasinghe et al. 2014). These time-dependent associations of exacerbated severity are also observed in a model in which allergy induction occurred after influenza infection (Kawaguchi et al. 2017). These models showed a reduction in the numbers of eosinophils migrating to the lung, deteriorated lung function, and increased allergic inflammation (Ravanetti et al. 2017). The bronchoalveolar lavage fluid from infected mice with allergic asthma had significantly higher IL-6, IL-10, TNF- $\alpha$, IL-5, IFN- $\alpha$, IFN- $\beta$, and IFN- $\lambda$ levels than those from infected, nonasthmatic mice (Hasegawa et al. 2014).

Although these studies provide a mechanistic explanation for the observation that asthmatics, once hospitalized for influenza, are less likely to die than other patient groups (Van Kerkhove et al. 2011), it also remains possible that different subtypes of asthma display differing degrees of synergism with influenza virus. Approximately $40 \%$ of adults suffer from allergic "eosinophilic asthma" modeled in mice by the different allergen triggers mentioned above; a large percentage of asthma patients suffer from nonallergic asthma (asthma is observed in the absence of allergen-specific IgE), neutrophilic asthma (eosinophilia cannot be detected), and 
R. Honce et al.

paucigranulocytic asthma (defined by absence of an inflammatory cell infiltrate in sputum) (Simpson et al. 2006). Developing suitable animal models for varying phenotypes will help determine if asthma subsets display a different relationship with influenza virus.

\section{Smoking, Chronic Obstructive Pulmonary Disease, and Emphysema}

Active and ex-smokers have increased susceptibility to severe disease upon infection (Kark et al. 1982; Godoy et al. 2018). In mouse models, chronic cigarette smoke exposure (CSE) leads to increased lung inflammation and viral titers on infection compared with mice exposed to only fresh air (Gualano et al. 2008; Wang et al. 2015; Hong et al. 2018). Earlier CSE heightens migration of macrophages and neutrophils to the lungs and blunts the IFN, humoral, and $\gamma \delta$ T-cell responses in infected mice (Gualano et al. 2008; Wang et al. 2015; Hong et al. 2018). Mitigating the CSE-induced proinflammatory state via neutralizing antibodies against IL- $1 \alpha$ and IL$1 \beta$ improves infection outcomes (Bucher et al. 2017). Conversely, Han et al. (2014) contend the immunosuppressive effect of nicotine reduces inflammatory cell migration to the lung, thereby reducing immunopathology and promoting survival on influenza infection. These contradictory findings may be due to the duration and intensity of CSE. Work performed with primary respiratory epithelial cells from smokers or nonsmokers suggests a generally immunosuppressive state, as smoking reduced antiviral responses via downregulation of RIG-I- and TLR-3-mediated IFN signaling (Wu et al. 2016).

Smoking exacerbates chronic obstructive pulmonary disease (COPD) and emphysemalike symptoms, and the interactions among these chronic states impact influenza pathogenesis (Leung et al. 2017). CSE has been used to model the development of emphysema and COPD in mice (Bauer et al. 2010; Vijayan 2013; Mebratu et al. 2016). In these mouse models, increased viral titers, pulmonary inflammation, and reduced lung elasticity are reported on influenza infection (Bauer et al. 2010; Hsu et al. 2015). The severe inflammatory response is preceded by di- minished innate immune responses, including poor mitochondrial antiviral-signaling (MAVS) and phosphoinositide 3-kinase (PI3K) signaling in lung epithelium (Hsu et al. 2015, 2017). CSEinduced COPD mice show NK cell hyperresponsiveness and enhanced neutrophilic responses, which further exacerbate viral-induced inflammation (Wortham et al. 2012; Sichelstiel et al. 2014). Experiments using influenza infection of primary human epithelial cells derived from donors with COPD support these findings, with increased viral entry and replication, impaired IFN responses, and heightened oxidative stress (Hsu et al. 2015; Aizawa et al. 2018).

Therapeutic strategies aimed at reducing lung inflammation are effective in improving antiviral responses in the COPD mouse model. Targeting signaling pathways to induce increased IFN production early in infection, or the application of exogenous IFN, can improve the antiviral response and may improve responses in other high-risk states as well (Hsu et al. 2015, 2017). Further, blocking the cytokine and chemokine signals that heighten NK cell and neutrophilic inflammation constrain aberrant inflammation and preserve lung function (Botelho et al. 2011; Sichelstiel et al. 2014).

\section{Chronic, Genetic, and Infectious Diseases}

Although influenza virus infection is typically self-limiting, in those with chronic disease severe sequalae can arise (WHO 2018). Type II diabetes and metabolic syndrome are known risk factors for severe influenza virus disease (Allard et al. 2010) and are prevalent among obese individuals. Type II diabetes results in increased susceptibility to influenza infection as shown by a lower lethal dose-50 and greater morbidity on infection in diabetic mice (Ito et al. 2015). Further, type I diabetics also suffer greater disease, and models of autoimmune diabetes show higher viral titers correlating with blood glucose levels and impaired viral clearance (Huo et al. 2017). (The impact of type I and type II diabetes on influenza severity is further reviewed in Hulme et al. 2017.)

Cystic fibrosis (CF) is one of the most-studied genetic disorders that impacts influenza 
pathogenesis, as it increases susceptibility to influenza infection while also increasing CF complications (Conway et al. 1992; Renk et al. 2014). Cell culture models of the CF human respiratory epithelium report reduced antiviral gene induction early on in infection, but heightened inflammatory gene responses late in infection, contributing to the same pathology seen in mouse models (Xu et al. 2006). As influenza infection can result in lung edema and pulmonary fluid imbalance, the CF-related impairments in ion flux and fluid balance are exacerbated (Wolk et al. 2008; Brand et al. 2018). Interestingly, CF transmembrane conductance regulator gene heterozygotic mice have improved outcomes postinfection, including reduced acute lung injury, because of increased TGF- $\beta$-induced IL- 6 production and stimulation of alveolar macrophages (Aeffner et al. 2013; Woods et al. 2015). Murine models of other genetic diseases, including sickle cell and neurodevelopmental disorders, display increased disease severity and blunted antiviral immunity, thus supporting the higher burdens and increased morbidity reported in clinical and epidemiological studies (Bundy et al. 2010; Strouse et al. 2010; Centers for Disease Control and Prevention 2012; Burton et al. 2014; Cronk et al. 2017; Karlsson et al. 2017b).

Underlying co-infections may also play into poor immune responses during influenza infections (Thompson et al. 2012; Sansonetti et al. 2014). Mycobacterium tuberculosis infection is a leading cause of morbidity and mortality worldwide, with increased risks of death in those coinfected with influenza virus (Walaza et al. 2015). In mouse models, earlier exposure to influenza virus increases mycobacterial growth and decreases survival caused by enhanced antiviral type I IFN signaling that diminishes the IFN- $\gamma$ signaling crucial for mycobacterial control (Manca et al. 2005; Redford et al. 2014). Concurrent influenza infections are common in those already burdened with mycobacteria and may diminish IFN- $\gamma$-dependent $\mathrm{CD}^{+} \mathrm{T}$ cell responses needed to clear the bacterium and increase IL-10 levels (Flórido et al. 2013; Ring et al. 2019). Improved mycobacterial clearance during influenza coinfection is achieved by blocking IL-10 receptor signaling (Ring et al. 2019). In HIV-infected hosts, other comorbidities drive increased susceptibility to influenza infection (Sheth et al. 2011; González Álvarez et al. 2016). Age, nutritional status, intravenous drug use, and CSE can all impact susceptibility to influenza virus infection and disease severity in the HIV-positive population (Sheth et al. 2011; Short et al. 2018).

\section{PROTECTING HIGH-RISK POPULATIONS}

Seasonal vaccination remains the safest and most efficacious way to prevent influenza infection and reduce disease severity, although not all hosts respond adequately to these preventative measures (Kennedy et al. 2012; Green and Beck 2017; Zerbo et al. 2017; Dhakal and Klein 2019). Because of the altered immune system in obese models, it is not surprising that the influenza vaccine is less efficacious in obese individuals (Neidich et al. 2017). Genetically obese mice vaccinated both with and without adjuvant were not protected against homologous viral challenge (Karlsson et al. 2016). Although the addition of adjuvant improves seroconversion in genetically obese animals, the breadth and magnitude of the antibody responses to HA and NA proteins are decreased, with no discernible impact from increasing antigen amount (Karlsson et al. 2016). The antibody response to influenza vaccination also declines faster in DIO mice versus lean controls. By 3 wk postvaccination, antibody titers diminish in obese mice, whereas they continue to increase in lean mice (Cho et al. 2016). Influenza vaccination has no effect on mortality during secondary bacterial infection, although survival could be improved by treating obese mice with $\beta$-lactam (Karlsson et al. 2017a). Passive antibody transfer using sera from lean mice also fails to protect obese mice, suggesting the obese host response may be more important than antibody protection (Karlsson et al. 2016). In mice that model type II diabetes, vaccination is shown to be effective (Sheridan et al. 2015), and type I diabetic mice show protection from viral challenge after vaccination with multiple-dose or high-dose vaccines (Zhu et al. 2005; Wu et al. 2010; Kreuzer et al. 2015). 
R. Honce et al.

Vaccination is efficacious during pregnancy and can also safely protect the neonate (Beigi et al. 2009; Kennedy et al. 2012). Immunization during later gestational periods shows higher maternal immune activation and transmission to the fetus, but quicker antibody waning in the mother versus vaccination during the first or second trimester (Cuningham et al. 2019). For the fetus and neonate, passive transfer of antibodies via placenta or in breast milk can be protective; however, maternal vaccination during early pregnancy may wane and be ineffective in the neonate (Reuman et al. 1983; Mbawuike et al. 1990; Honda-Okubo et al. 2014; van der Lubbe et al. 2017; Cuningham et al. 2019). The benefits of maternal vaccination on fetal and neonatal survival is also evident for $\mathrm{H} 5 \mathrm{~N} 1 \mathrm{vac}-$ cination and challenge in mice, highlighting the benefits of breastfeeding for influenza-infected neonates and the uptake of vaccines in the pregnant cohort (Beigi et al. 2009; Satpathy et al. 2009; Hwang et al. 2010; Steinhoff et al. 2010; Christian et al. 2017). After infection, administration of antivirals can reduce disease severity and limit the duration of infection, with early administration crucial for the pregnant host (Siston et al. 2010; Centers for Disease Control and Prevention 2011). Unlike what was reported in clinical trials, pregnant women may have increased clearance of peramivir (Clay et al. 2011), stressing the need for inclusion of pregnant women in more clinical trials and the use of pregnant animal models to study the pharmacokinetics and efficacy of other antivirals.

Because of the differences in influenza virus immunity and disease severity between age groups, there are age-specific influenza vaccination recommendations worldwide. Because of their short immune history, young children (6 mo to $8 \mathrm{yr}$ of age) in the United States are recommended to receive 1-2 doses of influenza vaccine annually (Neuzil et al. 2006; Campbell and Grohskopf 2018; Dhakal and Klein 2019). In the United States and other select countries, a high-dose influenza vaccine is available for those individuals $\geq 65 \mathrm{yr}$ old. This recommendation is supported by observations that aged mice require higher antigen doses to elicit immune responses comparable to younger mice because of immunosenescence (Yam et al. 2016). Despite the important role of biological sex on influenza virus immunity and disease described above, sex differences in vaccine efficacy decrease in aged mice (Potluri et al. 2019). Furthermore, the live-attenuated influenza vaccine is not recommended for individuals $<2$-yr-old or $>49$-yr-old because of their higher susceptibility to severe influenza virus disease (Grohskopf et al. 2018). (The role of host factors in influenza virus vaccination efficacy is further reviewed in Dhakal and Klein 2019.)

Vaccination proves effective in mice with allergic airway disease (Jian et al. 2013), but there are limited animal studies defining how other comorbidities impact both vaccination efficacy as well as antiviral efficacy. Further study on vaccination efficacy caused by the underlying coinfections and chronic genetic disorders, as well as understanding the dynamics of all influenza antiviral classes in high-risk hosts, is of exceeding importance; however, appropriate animal models must be developed to answer these targeted questions.

\section{CONCLUDING REMARKS}

Differing influenza pathogenesis in comorbid states and across the life span highlights the need for a carefully controlled and appropriately timed immune response to clear the virus and maintain airway integrity. The severity of an influenza virus infection represents a complex interplay between host and viral factors. However, as the number of people living with one or more comorbidity continues to increase, the role of host factors in influenza virus pathogenesis becomes ever more important (Fig. 3). Animal models of disease represent a powerful tool to understand and ultimately prevent severe influenza in vulnerable patient groups. Each animal model has limitations and caveats, but continued investigation into influenza infections in animal models of high-risk hosts represent an important first step toward reducing the burden of influenza in the twenty-first century. With increasing demands for universal influenza vaccines, the availability of such animal models will help ensure that any novel vaccine candidate is 


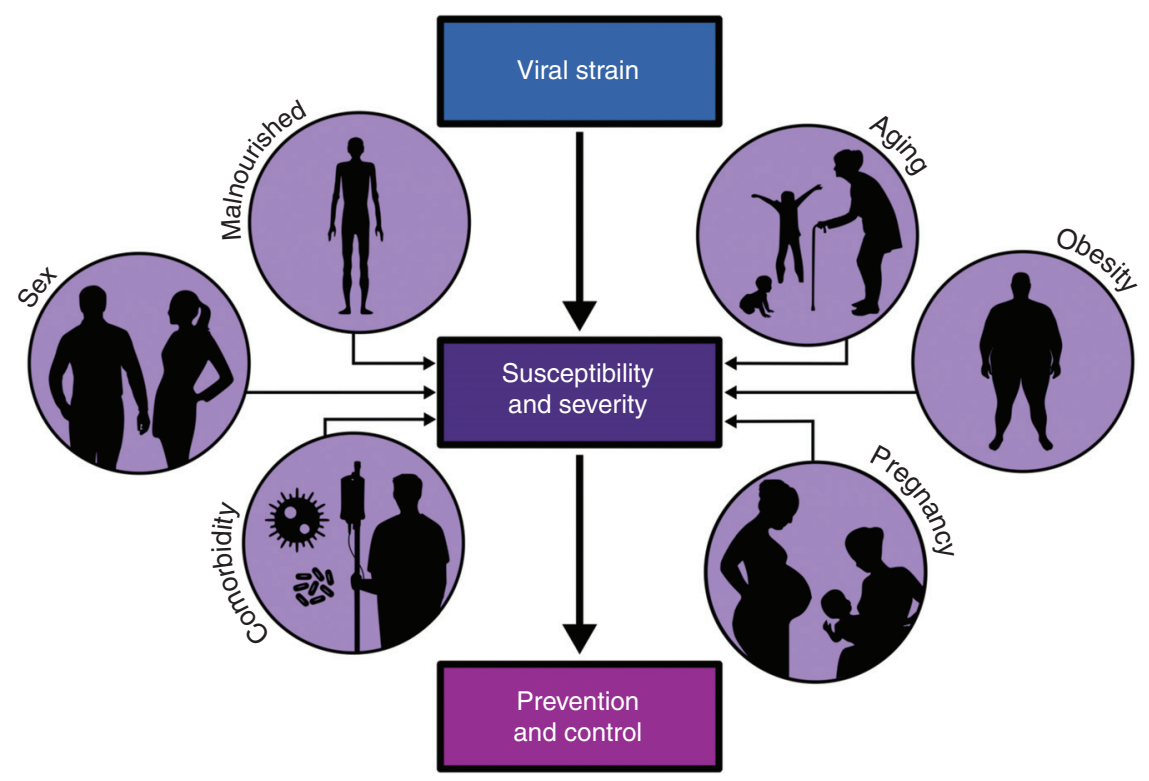

Figure 3. Host characteristics that contribute to influenza virus pathogenesis. High-risk hosts often have aberrant immune responses and baseline characteristics that impact susceptibility to infection with various influenza viral strains, as well as the antiviral response on infection. Studying influenza pathogenesis in the context of these hosts is of paramount importance, as the number of those living with one or more comorbidities continues to increase.

efficacious not only in healthy adults but also in those populations most at risk of severe influenza (Erbelding et al. 2018; Henry et al. 2018).

\section{ACKNOWLEDGMENTS}

S.S.-C. is supported by the National Institute of Allergy and Infectious Diseases (NIAID) Centers of Excellence in Influenza Virus Research and Surveillance (CEIRS) contract HHSN27220 1400006C, American Lebanese Syrian Associated Charities (ALSAC), and 1R01AI14076601A1. K.R.S. is supported by the Australian Research Council DE180100512. Statistical analyses were done in GraphPad Prism 8 with figures finalized in Inkscape and bioRender.

This article has been made freely available online courtesy of TAUNS Laboratories.

\section{REFERENCES}

Aeffner F, Abdulrahman B, Hickman-Davis JM, Janssen PM, Amer A, Bedwell DM, Sorscher EJ, Davis IC. 2013. Heterozygosity for the F508del mutation in the cystic fibrosis transmembrane conductance regulator anion channel attenuates influenza severity. J Infect Dis 208: 780-789. doi:10.1093/infdis/jit251

Aizawa H, Koarai A, Shishikura Y, Yanagisawa S, Yamaya M, Sugiura H, Numakura T, Yamada M, Ichikawa T, Fujino $\mathrm{N}$, et al. 2018. Oxidative stress enhances the expression of IL-33 in human airway epithelial cells. Respir Res 19: 52. doi:10.1186/s12931-018-0752-9

Albrecht RA, Liu WC, Sant AJ, Tompkins SM, Pekosz A, Meliopoulos V, Cherry S, Thomas PG, Schultz-Cherry S. 2018. Moving forward: recent developments for the ferret biomedical research model. mBio 9: e01113-18. doi:10 $.1128 / \mathrm{mBio} .01113-18$

Allard R, Leclerc P, Tremblay C, Tannenbaum TN. 2010. Diabetes and the severity of pandemic influenza A (H1N1) infection. Diabetes Care 33: 1491-1493. doi:10 $.2337 / \mathrm{dc} 09-2215$

Avitsur R, Mays JW, Sheridan JF. 2011. Sex differences in the response to influenza virus infection: modulation by stress. Horm Behav 59: 257-264. doi:10.1016/j.yhbeh .2010 .12 .002

Bauer CM, Zavitz CC, Botelho FM, Lambert KN, Brown EG, Mossman KL, Taylor JD, Stämpfli MR. 2010. Treating viral exacerbations of chronic obstructive pulmonary disease: insights from a mouse model of cigarette smoke and H1N1 influenza infection. PLoS ONE 5: e13251. doi:10 .1371 /journal.pone.0013251

Beck MA. 2001. Antioxidants and viral infections: host immune response and viral pathogenicity. J Am Coll Nutr 20: 384S-388S. discussion 396S-397S. doi:10.1080/ 07315724.2001 .10719172 
R. Honce et al.

Beck MA, Nelson HK, Shi Q, Van Dael P, Schiffrin EJ, Blum S, Barclay D, Levander OA. 2001. Selenium deficiency increases the pathology of an influenza virus infection. FASEB J 15: 1481-1483. doi:10.1096/fj.00-0721fje

Beigi RH, Wiringa AE, Bailey RR, Assi TM, Lee BY. 2009. Economic value of seasonal and pandemic influenza vaccination during pregnancy. Clin Infect Dis 49: 1784-1792. doi:10.1086/649013

Beijar EC, Mallard C, Powell TL. 2006. Expression and subcellular localization of TLR-4 in term and first trimester human placenta. Placenta 27: 322-326. doi:10.1016/j placenta.2004.12.012

Botelho FM, Bauer CM, Finch D, Nikota JK, Zavitz CC, Kelly A, Lambert KN, Piper S, Foster ML, Goldring JJ, et al. 2011. IL-1 $\alpha /$ IL-1R1 expression in chronic obstructive pulmonary disease and mechanistic relevance to smokeinduced neutrophilia in mice. PLoS ONE 6: e28457. doi:10.1371/journal.pone.0028457

Brand JD, Lazrak A, Trombley JE, Shei RJ, Adewale AT, Tipper JL, Yu Z, Ashtekar AR, Rowe SM, Matalon S, et al. 2018. Influenza-mediated reduction of lung epithelial ion channel activity leads to dysregulated pulmonary fluid homeostasis. JCI Insight 3. doi:10.1172/jci.insight.123467

Bucher H, Mang S, Keck M, Przibilla M, Lamb DJ, Schiele F, Wittenbrink M, Fuchs K, Jung B, Erb KJ, et al. 2017. Neutralization of both IL-1 $\alpha /$ IL-1 $\beta$ plays a major role in suppressing combined cigarette smoke/virus-induced pulmonary inflammation in mice. Pulm Pharmacol Ther 44: 96-105. doi:10.1016/j.pupt.2017.03.008

Bundy DG, Strouse JJ, Casella JF, Miller MR. 2010. Burden of influenza-related hospitalizations among children with sickle cell disease. Pediatrics 125: 234-243. doi:10.1542/ peds.2009-1465

Burton C, Vaudry W, Moore D, Bettinger JA, Tran D, Halperin SA, Scheifele DW. 2014. Burden of seasonal influenza in children with neurodevelopmental conditions. Pediatr Infect Dis J 33: 710-714. doi:10.1097/INF .0000000000000272

Campbell AJP, Grohskopf LA. 2018. Updates on influenza vaccination in children. Infect Dis Clin North Am 32: 75 89. doi:10.1016/j.idc.2017.11.005

Campfield LA, Smith FJ, Guisez Y, Devos R, Burn P. 1995. Recombinant mouse OB protein: evidence for a peripheral signal linking adiposity and central neural networks. Science 269: 546-549. doi:10.1126/science.7624778

Centers for Disease Control and Prevention (CDC). 2010. Estimates of deaths associated with seasonal influenzaUnited States, 1976-2007. MMWR Morb Mortal Wkly Rep 59: 1057-1062.

Centers for Disease Control and Prevention (CDC). 2011. Maternal and infant outcomes among severely ill pregnant and postpartum women with 2009 pandemic influenza A (H1N1) - United States, April 2009-August 2010. MMWR Morb Mortal Wkly Rep 60: 1193-1196.

Centers for Disease Control and Prevention (CDC). 2012. Severe influenza among children and young adults with neurologic and neurodevelopmental conditions-Ohio 2011. MMWR Morb Mortal Wkly Rep 60: 1729-1733.

Chan KH, Zhang AJ, To KK, Chan CC, Poon VK, Guo K, Ng F, Zhang QW, Leung VH, Cheung AN, et al. 2010. Wild type and mutant 2009 pandemic influenza A (H1N1) viruses cause more severe disease and higher mortality in pregnant $\mathrm{BALB} / \mathrm{c}$ mice. PLOS ONE 5: e13757. doi:10 .1371/journal.pone.0013757

Cho WJ, Lee DK, Lee SY, Sohn SH, Park HL, Park YW, Kim H, Nam JH. 2016. Diet-induced obesity reduces the production of influenza vaccine-induced antibodies via impaired macrophage function. Acta Virol 60: 298-306. doi:10.4149/av_2016_03_298

Christiaens I, Zaragoza DB, Guilbert L, Robertson SA, Mitchell BF, Olson DM. 2008. Inflammatory processes in preterm and term parturition. J Reprod Immunol 79: 50-57. doi:10.1016/j.jri.2008.04.002

Christian LM. 2014. Optimizing benefits of influenza virus vaccination during pregnancy: potential behavioral risk factors and interventions. Vaccine 32: 2958-2964. doi:10 .1016/j.vaccine.2014.03.075

Christian LM, Franco A, Iams JD, Sheridan J, Glaser R. 2010. Depressive symptoms predict exaggerated inflammatory responses to an in vivo immune challenge among pregnant women. Brain Behav Immun 24: 49-53. doi:10 .1016/j.bbi.2009.05.055

Christian LM, Beverly C, Mitchell AM, Karlsson E, Porter K, Schultz-Cherry S, Ramilo O. 2017. Effects of prior influenza virus vaccination on maternal antibody responses: implications for achieving protection in the newborns. Vaccine 35: 5283-5290. doi:10.1016/j.vaccine.2017.05 .050

Clay PG, Adiga RB, Taylor TA, Alsup R, Gerk PM, McRae M. 2011. Postpartum pharmacokinetics of peramivir in the treatment of 2009 H1N1 influenza. Obstet Gynecol 118: 463-467. doi:10.1097/AOG.0b013e31821b1b3e

Conway SP, Simmonds EJ, Littlewood JM. 1992. Acute severe deterioration in cystic fibrosis associated with influenza A virus infection. Thorax 47: 112-114. doi:10.1136/ thx.47.2.112

Cordeau M, Herblot S, Charrier E, Audibert F, Cordeiro P, Harnois M, Duval M. 2012. Defects in CD54 and CD86 up-regulation by plasmacytoid dendritic cells during pregnancy. Immunol Invest 41: 497-506. doi:10.3109/ 08820139.2012 .682243

Cronk JC, Herz J, Kim TS, Louveau A, Moser EK, Sharma AK, Smirnov I, Tung KS, Braciale TJ, Kipnis J. 2017. Influenza A induces dysfunctional immunity and death in MeCP2-overexpressing mice. JCI Insight 2: e88257. doi:10.1172/jci.insight. 88257

Cuningham W, Geard N, Fielding JE, Braat S, Madhi SA, Nunes MC, Christian LM, Lin SY, Lee CN, Yamaguchi K, et al. 2019. Optimal timing of influenza vaccine during pregnancy: a systematic review and meta-analysis. Influenza Other Respir Viruses 13: 438-452.

Dauer CC, Serfling RE. 1961. Mortality from influenza. Am Rev Respir Dis 83: 15-28.

Davis SM, Sweet LM, Oppenheimer KH, Suratt BT, Phillippe M. 2017. Estradiol and progesterone influence on influenza infection and immune response in a mouse model. Am J Reprod Immunol 78: e12695. doi:10.1111/aji.12695

Debeuf N, Haspeslagh E, van Helden M, Hammad H, Lambrecht BN. 2016. Mouse models of asthma. Curr Protoc Mouse Biol 6: 169-184. doi:10.1002/cpmo.4

de Wit E, Siegers JY, Cronin JM, Weatherman S, van den Brand JM, Leijten LM, van Run P, Begeman L, van den Ham HJ, Andeweg AC, et al. 2018. 1918 H1N1 influenza virus replicates and induces proinflammatory cytokine 
responses in extrarespiratory tissues of ferrets. J Infect Dis 217: 1237-1246. doi:10.1093/infdis/jiy003

Dhakal S, Klein SL. 2019. Host factors impact vaccine efficacy: implications for seasonal and universal influenza vaccine programs. J Virol 93. doi:10.1128/JVI.00797-19

Diavatopoulos DA, Short KR, Price JT, Wilksch JJ, Brown LE, Briles DE, Strugnell RA, Wijburg OL. 2010. Influenza A virus facilitates Streptococcus pneumoniae transmission and disease. FASEB J 24: 1789-1798. doi:10.1096/fj.09146779

Engels G, Hierweger AM, Hoffmann J, Thieme R, Thiele S, Bertram S, Dreier C, Resa-Infante P, Jacobsen H, Thiele K, et al. 2017. Pregnancy-related immune adaptation promotes the emergence of highly virulent H1N1 influenza virus strains in allogenically pregnant mice. Cell Host Microbe 21: 321-333. doi:10.1016/j.chom.2017.02.020

Erbelding EJ, Post DJ, Stemmy EJ, Roberts PC, Augustine AD, Ferguson S, Paules CI, Graham BS, Fauci AS. 2018. A universal influenza vaccine: the strategic plan for the $\mathrm{Na}$ tional Institute of Allergy and Infectious Diseases. J Infect Dis 218: 347-354. doi:10.1093/infdis/jiy103

Falsey AR, Hennessey PA, Formica MA, Cox C, Walsh EE. 2005. Respiratory syncytial virus infection in elderly and high-risk adults. New Engl J Med 352: 1749-1759. doi:10 .1056/NEJMoa043951

Fell DB, Savitz DA, Kramer MS, Gessner BD, Katz MA, Knight M, Luteijn JM, Marshall H, Bhat N, Gravett MG, et al. 2017. Maternal influenza and birth outcomes: systematic review of comparative studies. BJOG 124: 4859. doi:10.1111/1471-0528.14143

Flórido M, Grima MA, Gillis CM, Xia Y, Turner SJ, Triccas JA, Stambas J, Britton WJ. 2013. Influenza A virus infection impairs mycobacteria-specific $\mathrm{T}$ cell responses and mycobacterial clearance in the lung during pulmonary coinfection. J Immunol 191: 302-311. doi:10.4049/jimmu nol.1202824

Forbes RL, Wark PA, Murphy VE, Gibson PG. 2012. Pregnant women have attenuated innate interferon responses to 2009 pandemic influenza A virus subtype H1N1. Infect Dis 206: 646-653. doi:10.1093/infdis/jis377

Francis T. 1960. On the doctrine of original antigenic sin. Proc Am Philos Soc 104: 572-578.

Furuya Y, Furuya AK, Roberts S, Sanfilippo AM, Salmon SL, Metzger DW. 2015. Prevention of influenza virus-induced immunopathology by TGF- $\beta$ produced during allergic asthma. PLoS Pathog 11: e1005180. doi:10.1371/ journal.ppat.1005180

Ghoneim HE, Thomas PG, McCullers JA. 2013. Depletion of alveolar macrophages during influenza infection facilitates bacterial superinfections. J Immunol 191: 12501259. doi:10.4049/jimmunol.1300014

Gil A, Yassai MB, Naumov YN, Selin LK. 2015. Narrowing of human influenza A virus-specific T cell receptor $\alpha$ and $\beta$ repertoires with increasing age. J Virol 89: 4102-4116. doi:10.1128/JVI.03020-14

Glezen WP. 1996. Emerging infections: pandemic influenza. Epidemiol Rev 18: 64-76. doi:10.1093/oxfordjournals epirev.a017917

Godoy P, Castilla J, Soldevila N, Mayoral JM, Toledo D, Martín V, Astray J, Egurrola M, Morales-Suarez-Varela M, Domínguez A. 2018. Smoking may increase the risk of influenza hospitalization and reduce influenza vaccine effectiveness in the elderly. Eur J Public Health 28: 150155. doi:10.1093/eurpub/ckx130

Gold M, Marsolais D, Blanchet MR. 2015. Mouse models of allergic asthma. Methods Mol Biol 1220: 503-519. doi:10 .1007/978-1-4939-1568-2_31

Gonzalez JM, Ofori E, Burd I, Chai J, Scholler N, Elovitz MA. 2009. Maternal mortality from systemic illness: unraveling the contribution of the immune response. Am JObstet Gynecol 200: 430.e1-430.e8. doi:10.1016/j.ajog.2009.01 .049

González Álvarez DA, López Cortés LF, Cordero E. 2016. Impact of HIV on the severity of influenza. Expert Rev Respir Med 10: 463-472. doi:10.1586/17476348.2016 .1157474

Green WD, Beck MA. 2017. Obesity impairs the adaptive immune response to influenza virus. Ann Am Thorac Soc 14: S406-S409. doi:10.1513/AnnalsATS.201706-447AW

Grohskopf LA, Sokolow LZ, Broder KR, Walter EB, Fry AM, Jernigan DB. 2018. Prevention and control of seasonal influenza with vaccines: recommendations of the Advisory Committee on Immunization Practices-United States, 2018-19 influenza season. MMWR Morb Mortal Wkly Rep Recomm Rep 67: 1-20. doi:10.15585/mmwr .rr6703al

Gu X, Li P, Liu H, Li N, Li S, Sakuma T. 2011. The effect of influenza virus $A$ on th1/th2 balance and alveolar fluid clearance in pregnant rats. Exp Lung Res 37: 445-451. doi:10.3109/01902148.2011.587136

Gualano RC, Hansen MJ, Vlahos R, Jones JE, Park-Jones RA, Deliyannis G, Turner SJ, Duca KA, Anderson GP. 2008. Cigarette smoke worsens lung inflammation and impairs resolution of influenza infection in mice. Respir Res 9: 53. doi:10.1186/1465-9921-9-53

Guo XJ, Dash P, Crawford JC, Allen EK, Zamora AE, Boyd DF, Duan S, Bajracharya R, Awad WA, Apiwattanakul N, et al. 2018. Lung $\gamma \delta \mathrm{T}$ cells mediate protective responses during neonatal influenza infection that are associated with type 2 immunity. Immunity 49: 531-544.e6. doi:10 .1016/j.immuni.2018.07.011

Hall OJ, Limjunyawong N, Vermillion MS, Robinson DP, Wohlgemuth N, Pekosz A, Mitzner W, Klein SL. 2016. Progesterone-based therapy protects against influenza by promoting lung repair and recovery in females. PLoS Pathog 12: e1005840. doi:10.1371/journal.ppat.1005840

Hall OJ, Nachbagauer R, Vermillion MS, Fink AL, Phuong V, Krammer F, Klein SL. 2017. Progesterone-based contraceptives reduce adaptive immune responses and protection against sequential influenza A virus infections. $J$ Virol 91: e02160-16.

Han Y, Ling MT, Mao H, Zheng J, Liu M, Lam KT, Liu Y, Tu W, Lau YL. 2014. Influenza virus-induced lung inflammation was modulated by cigarette smoke exposure in mice. PLoS ONE 9: e86166. doi:10.1371/journal.pone .0086166

Härtel C, Humberg A, Viemann D, Stein A, Orlikowsky T, Rupp J, Kopp MV, Herting E, Göpel W. 2016. Preterm birth during influenza season is associated with adverse outcome in very low birth weight infants. Front Pediatr 4: 130. doi:10.3389/fped.2016.00130

Hasegawa S, Wakiguchi H, Okada S, Gui Kang Y, Fujii N, Hasegawa M, Hasegawa $\mathrm{H}$, Ainai A, Atsuta R, Shirabe K, et al. 2014. Cytokine profile of bronchoalveolar lavage 


\section{R. Honce et al.}

fluid from a mouse model of bronchial asthma during seasonal H1N1 infection. Cytokine 69: 206-210. doi:10 $.1016 /$ j.cyto.2014.06.006

Henry C, Palm AE, Krammer F, Wilson PC. 2018. From original antigenic sin to the universal influenza virus vaccine. Trends Immunol 39: 70-79. doi:10.1016/j.it.2017.08 .003

Honce R, Schultz-Cherry S. 2019. Impact of obesity on influenza A virus pathogenesis, immune response, and evolution. Front Immunol 10: 1071. doi:10.3389/fimmu.2019 .01071

Honda-Okubo Y, Kolpe A, Li L, Petrovsky N. 2014. A single immunization with inactivated $\mathrm{H} 1 \mathrm{~N} 1$ influenza vaccine formulated with delta inulin adjuvant (Advax $\left.{ }^{\mathrm{TM}}\right)$ overcomes pregnancy-associated immune suppression and enhances passive neonatal protection. Vaccine 32: 4651-4659. doi:10.1016/j.vaccine.2014.06.057

Hong MJ, Gu BH, Madison MC, Landers C, Tung HY, Kim M, Yuan X, You R, Machado AA, Gilbert BE, et al. 2018. Protective role of $\gamma \delta \mathrm{T}$ cells in cigarette smoke and influenza infection. Mucosal Immunol 11: 894-908. doi:10 $.1038 / \mathrm{mi} .2017 .93$

Hsu AC, Starkey MR, Hanish I, Parsons K, Haw TJ, Howland LJ, Barr I, Mahony JB, Foster PS, Knight DA, et al. 2015. Targeting PI3K-p110 $\alpha$ suppresses influenza virus infection in chronic obstructive pulmonary disease. Am J Respir Crit Care Med 191: 1012-1023. doi:10.1164/rccm .201501-0188OC

Hsu AC, Dua K, Starkey MR, Haw TJ, Nair PM, Nichol K, Zammit N, Grey ST, Baines KJ, Foster PS, et al. 2017. MicroRNA-125a and -b inhibit A20 and MAVS to promote inflammation and impair antiviral response in COPD. JCI Insight 2: e90443. doi:10.1172/jci.insight .90443

Huang SS, Banner D, Degousee N, Leon AJ, Xu L, Paquette SG, Kanagasabai T, Fang Y, Rubino S, Rubin B, et al. 2012 Differential pathological and immune responses in newly weaned ferrets are associated with a mild clinical outcome of pandemic 2009 H1N1 infection. J Virol 86: 1318713201. doi:10.1128/JVI.01456-12

Hulme KD, Gallo LA, Short KR. 2017. Influenza virus and glycemic variability in diabetes: a killer combination? Front Microbiol 8: 861. doi:10.3389/fmicb.2017.00861

Huo C, Zhang S, Zhang S, Wang M, Qi P, Xiao J, Hu Y, Dong H. 2017. Mice with type 1 diabetes exhibit increased susceptibility to influenza A virus. Microb Pathog 113: 233241. doi:10.1016/j.micpath.2017.10.026

Hwang SD, Shin JS, Ku KB, Kim HS, Cho SW, Seo SH. 2010. Protection of pregnant mice, fetuses and neonates from lethality of $\mathrm{H} 5 \mathrm{~N} 1$ influenza viruses by maternal vaccination. Vaccine 28: 2957-2964. doi:10.1016/j.vaccine.2010 .02 .016

Ilievski V, Lu SJ, Hirsch E. 2007. Activation of toll-like receptors 2 or 3 and preterm delivery in the mouse. Reprod Sci 14: 315-320. doi:10.1177/1933719107302959

Ingersoll MA. 2017. Sex differences shape the response to infectious diseases. PLoS Pathog 13: e1006688. doi:10 .1371/journal.ppat.1006688

Irving WL, James DK, Stephenson T, Laing P, Jameson C, Oxford JS, Chakraverty P, Brown DW, Boon AC, Zambon MC. 2000. Influenza virus infection in the second and third trimesters of pregnancy: a clinical and seroepide- miological study. BJOG 107: 1282-1289. doi:10.1111/j .1471-0528.2000.tb11621.x

Ishikawa H, Sasaki H, Fukui T, Fujita K, Kutsukake E, Matsumoto T. 2012. Mice with asthma are more resistant to influenza virus infection and NK cells activated by the induction of asthma have potentially protective effects. J Clin Immunol 32: 256-267. doi:10.1007/s10875-0119619-2

Ito M, Kubota $\mathrm{H}$, Takeuchi T, Qia S, Tsurudome M, Tsumur H, Matsuda A, Nishio M, Ito Y. 2015. Pathogenesis of the influenza virus in diabetes model mice. BMRJ 9: 1-7. doi:10.9734/BMRJ/2015/18799

Jensen-Fangel S, Mohey R, Johnsen SP, Andersen PL, Sørensen HT, Østergaard L. 2004. Gender differences in hospitalization rates for respiratory tract infections in Danish youth. Scand J Infect Dis 36: 31-36. doi:10 $.1080 / 00365540310017618$

Jian YR, Chang SY, Lin PY, Yang YH, Chuang YH. 2013. Inactivated influenza virus vaccine is efficient and reduces IL-4 and IL-6 in allergic asthma mice. Influenza Other Respir Viruses 7: 1210-1217. doi:10.1111/irv.12150

Johnson-Delaney CA, Orosz SE. 2011. Ferret respiratory system: clinical anatomy, physiology, and disease. Vet Clin North Am Exot Anim Pract 14: 357-367, vii. doi:10.1016/j cvex.2011.03.001

Kark JD, Lebiush M, Rannon L. 1982. Cigarette smoking as a risk factor for epidemic $\mathrm{A}(\mathrm{H} 1 \mathrm{~N} 1)$ influenza in young men. New Engl J Med 307: 1042-1046. doi:10.1056/ NEJM198210213071702

Karlsson EA, Sheridan PA, Beck MA. 2010. Diet-induced obesity in mice reduces the maintenance of influenzaspecific CD8 ${ }^{+}$memory T cells. J Nutr 140: 1691-1697. doi:10.3945/jn.110.123653

Karlsson EA, Hertz T, Johnson C, Mehle A, Krammer F, Schultz-Cherry S. 2016. Obesity outweighs protection conferred by adjuvanted influenza vaccination. mBio 7 . doi:10.1128/mBio.01144-16

Karlsson EA, Meliopoulos VA, van de Velde NC, van de Velde LA, Mann B, Gao G, Rosch J, Tuomanen E, McCullers J, Vogel P, et al. 2017a. A perfect storm: increased colonization and failure of vaccination leads to severe secondary bacterial infection in influenza virus-infected obese mice. $m$ Bio 8 . doi:10.1128/mBio.00889-17

Karlsson EA, Oguin TH, Meliopoulos V, Iverson A, Broadnax A, Yoon SW, Pestina T, Thomas P, Webby R, SchultzCherry S, et al. 2017b. Vascular permeability drives susceptibility to influenza infection in a murine model of sickle cell disease. Sci Rep 7: 43308. doi:10.1038/ srep 43308

Kash JC, Tumpey TM, Proll SC, Carter V, Perwitasari O, Thomas MJ, Basler CF, Palese P, Taubenberger JK, García-Sastre A, et al. 2006. Genomic analysis of increased host immune and cell death responses induced by 1918 influenza virus. Nature 443: 578-581. doi:10.1038/na ture05181

Kawaguchi A, Suzuki T, Ohara Y, Takahashi K, Sato Y, Ainai A, Nagata N, Tashiro M, Hasegawa H. 2017. Impacts of allergic airway inflammation on lung pathology in a mouse model of influenza A virus infection. PLoS ONE 12: e0173008. doi:10.1371/journal.pone. 0173008

Kay AW, Fukuyama J, Aziz N, Dekker CL, Mackey S, Swan GE, Davis MM, Holmes S, Blish CA. 2014. Enhanced 
natural killer-cell and T-cell responses to influenza A virus during pregnancy. Proc Natl Acad Sci 111: $14506-$ 14511. doi:10.1073/pnas.1416569111

Kennedy ED, Ahluwalia IB, Ding H, Lu PJ, Singleton JA, Bridges CB. 2012. Monitoring seasonal influenza vaccination coverage among pregnant women in the United States. Am J Obstet Gynecol 207: S9-S16. doi:10.1016/j .ajog.2012.06.069

Kim HM, Kang YM, Song BM, Kim HS, Seo SH. 2012a. The 2009 pandemic H1N1 influenza virus is more pathogenic in pregnant mice than seasonal H1N1 influenza virus. Viral Immunol 25: 402-410. doi:10.1089/vim.2012.0007

Kim YH, Kim JK, Kim DJ, Nam JH, Shim SM, Choi YK, Lee CH, Poo H. 2012b. Diet-induced obesity dramatically reduces the efficacy of a 2009 pandemic H1N1 vaccine in a mouse model. J Infect Dis 205: 244-251. doi:10.1093/ infdis/jir731

Kim JC, Kim HM, Kang YM, Ku KB, Park EH, Yum J, Kim JA, Kang YK, Lee JS, Kim HS, et al. 2014. Severe pathogenesis of influenza B virus in pregnant mice. Virology 448: 74-81. doi:10.1016/j.virol.2013.10.001

Klein SL, Passaretti C, Anker M, Olukoya P, Pekosz A. 2010 The impact of sex, gender and pregnancy on $2009 \mathrm{H} 1 \mathrm{~N} 1$ disease. Biol Sex Differ 1: 5. doi:10.1186/2042-6410-1-5

Klein SL, Hodgson A, Robinson DP. 2012. Mechanisms of sex disparities in influenza pathogenesis. J Leukoc Biol 92: 67-73. doi:10.1189/jlb.0811427

Kobasa D, Takada A, Shinya K, Hatta M, Halfmann P, Theriault S, Suzuki H, Nishimura H, Mitamura K, Sugaya N, et al. 2004. Enhanced virulence of influenza A viruses with the haemagglutinin of the 1918 pandemic virus. Nature 431: 703-707. doi:10.1038/nature02951

Kobasa D, Jones SM, Shinya K, Kash JC, Copps J, Ebihara H, Hatta Y, Kim JH, Halfmann P, Hatta M, et al. 2007. Aberrant innate immune response in lethal infection of macaques with the 1918 influenza virus. Nature 445: 319-323. doi:10.1038/nature05495

Koga K, Izumi G, Mor G, Fujii T, Osuga Y. 2014. Toll-like receptors at the maternal-fetal interface in normal pregnancy and pregnancy complications. Am J Reprod Immunol 72: 192-205. doi:10.1111/aji.12258

Kondrich J, Rosenthal M. 2017. Influenza in children. Curr Opin Pediatr 29: 297-302. doi:10.1097/MOP .0000000000000495

Kosaraju R, Guesdon W, Crouch MJ, Teague HL, Sullivan EM, Karlsson EA, Schultz-Cherry S, Gowdy K, Bridges LC, Reese LR, et al. 2017. B cell activity is impaired in human and mouse obesity and is responsive to an essential fatty acid upon murine influenza infection. J Immunol 198: 4738-4752. doi:10.4049/jimmunol.1601031

Krammer F, Pica N, Hai R, Margine I, Palese P. 2013. Chimeric hemagglutinin influenza virus vaccine constructs elicit broadly protective stalk-specific antibodies. J Virol 87: 6542-6550. doi:10.1128/JVI.00641-13

Krammer F, Margine I, Hai R, Flood A, Hirsh A, Tsvetnitsky V, Chen D, Palese P. 2014. H3 stalk-based chimeric hemagglutinin influenza virus constructs protect mice from H7N9 challenge. J Virol 88: 2340-2343. doi:10.1128/JVI .03183-13

Kraus TA, Sperling RS, Engel SM, Lo Y, Kellerman L, Singh T, Loubeau M, Ge Y, Garrido JL, Rodríguez-García M et al. 2010. Peripheral blood cytokine profiling during pregnancy and post-partum periods. Am J Reprod Immunol 64: 411-426. doi:10.1111/j.1600-0897.2010.00889.x

Kreuzer D, Nikoopour E, Au BC, Krougly O, Lee-Chan E, Summers KL, Haeryfar SM, Singh B. 2015. Reduced interferon- $\alpha$ production by dendritic cells in type 1 diabetes does not impair immunity to influenza virus. Clin Exp Immunol 179: 245-255. doi:10.1111/cei.12462

Lafond KE, Nair H, Rasooly MH, Valente F, Booy R, Rahman M, Kitsutani P, Yu H, Guzman G, Coulibaly D, et al. 2016. Global role and burden of influenza in pediatric respiratory hospitalizations, 1982-2012: a systematic analysis. PLoS Med 13: e1001977. doi:10.1371/journal .pmed.1001977

Lee VJ, Ho ZJM, Goh EH, Campbell H, Cohen C, Cozza V, Fitzner J, Jara J, Krishnan A, Bresee J. 2018. Advances in measuring influenza burden of disease. Influenza Other Respir Viruses 12: 3-9. doi:10.1111/irv.12533

Le Gars M, Kay AW, Bayless NL, Aziz N, Dekker CL, Swan GE, Davis MM, Blish CA. 2016. Increased proinflammatory responses of monocytes and plasmacytoid dendritic cells to influenza A virus infection during pregnancy. $J$ Infect Dis 214: 1666-1671. doi:10.1093/infdis/jiw448

Leung JM, Tiew PY, Mac Aogáin M, Budden KF, Yong VF, Thomas SS, Pethe K, Hansbro PM, Chotirmall SH. 2017. The role of acute and chronic respiratory colonization and infections in the pathogenesis of COPD. Respirology 22: 634-650. doi:10.1111/resp.13032

Li W, Maeda N, Beck MA. 2006. Vitamin C deficiency increases the lung pathology of influenza virus-infected gulo $^{-1-}$ mice. J Nutr 136: 2611-2616. doi:10.1093/jn/ 136.10.2611

Littauer EQ, Skountzou I. 2018. Hormonal regulation of physiology, innate immunity and antibody response to H1N1 influenza virus infection during pregnancy. Front Immunol 9: 2455. doi:10.3389/fimmu.2018.02455

Littauer EQ, Esser ES, Antao OQ, Vassilieva EV, Compans RW, Skountzou I. 2017. H1N1 influenza virus infection results in adverse pregnancy outcomes by disrupting tissue-specific hormonal regulation. PLoS Pathog 13: e1006757. doi:10.1371/journal.ppat.1006757

Lorenzo ME, Hodgson A, Robinson DP, Kaplan JB, Pekosz A, Klein SL. 2011. Antibody responses and cross protection against lethal influenza $A$ viruses differ between the sexes in C57BL/6 mice. Vaccine 29: 9246-9255. doi:10 $.1016 /$ j.vaccine.2011.09.110

Luk J, Gross P, Thompson WW. 2001. Observations on mortality during the 1918 influenza pandemic. Clin Infect Dis 33: 1375-1378. doi:10.1086/322662

Lutz TA, Woods SC. 2012. Overview of animal models of obesity. Curr Protoc Pharmacol Chapter 5: Unit5.61. doi: 10.1002/0471141755.ph0561s58

Manca C, Tsenova L, Freeman S, Barczak AK, Tovey M, Murray PJ, Barry C, Kaplan G. 2005. Hypervirulent M. tuberculosis W/Beijing strains upregulate type I IFNs and increase expression of negative regulators of the JakStat pathway. I Interferon Cytokine Res 25: 694-701. doi:10.1089/jir.2005.25.694

Marcelin G, Aldridge JR, Duan S, Ghoneim HE, Rehg J, Marjuki H, Boon AC, McCullers JA, Webby RJ. 2011. Fatal outcome of pandemic H1N1 2009 influenza virus infection is associated with immunopathology and impaired lung repair, not enhanced viral burden, in preg- 
R. Honce et al.

nant mice. J Virol 85: 11208-11219. doi:10.1128/JVI .00654-11

Margine I, Krammer F, Hai R, Heaton NS, Tan GS, Andrews SA, Runstadler JA, Wilson PC, Albrecht RA, GarcíaSastre A, et al. 2013. Hemagglutinin stalk-based universal vaccine constructs protect against group 2 influenza A viruses. J Virol 87: 10435-10446. doi:10.1128/JVI .01715-13

Mayer AE, Parks GD. 2014. An AGM model for changes in complement during pregnancy: neutralization of influen$\mathrm{za}$ virus by serum is diminished in late third trimester. PLoS ONE 9: e112749. doi:10.1371/journal.pone.0112749

Mbawuike IN, Six HR, Cate TR, Couch RB. 1990. Vaccination with inactivated influenza A virus during pregnancy protects neonatal mice against lethal challenge by influenza A viruses representing three subtypes. J Virol 64: 1370-1374.

McGregor JA, Burns JC, Levin MJ, Burlington B, Meiklejohn G. 1984. Transplacental passage of influenza A/Bangkok (H3N2) mimicking amniotic fluid infection syndrome. Am J Obstet Gynecol 149: 856-859. doi:10.1016/00029378(84)90604-5

Mebratu YA, Smith KR, Agga GE, Tesfaigzi Y. 2016. Inflammation and emphysema in cigarette smoke-exposed mice when instilled with poly (I:C) or infected with influenza A or respiratory syncytial viruses. Respir Res 17: 75. doi:10 1186/s12931-016-0392-x

Meliopoulos VA, Van de Velde LA, Van de Velde NC, Karlsson EA, Neale G, Vogel P, Guy C, Sharma S, Duan S, Surman SL, et al. 2016. An epithelial integrin regulates the amplitude of protective lung interferon responses against multiple respiratory pathogens. PLoS Pathog 12: e1005804. doi:10.1371/journal.ppat.1005804

Meliopoulos V, Livingston B, Van de Velde LA, Honce R, Schultz-Cherry S. 2019. Absence of $\beta 6$ integrin reduces influenza disease severity in highly susceptible obese mice. J Virol 93: e01646-18.

Memoli MJ, Tumpey TM, Jagger BW, Dugan VG, Sheng ZM, Qi L, Kash JC, Taubenberger JK. 2009. An early "classical" swine H1N1 influenza virus shows similar pathogenicity to the 1918 pandemic virus in ferrets and mice. Virology 393: 338-345. doi:10.1016/j.virol.2009.08 .021

Metzger DW, Sun K. 2013. Immune dysfunction and bacterial coinfections following influenza. J Immunol 191: 2047-2052. doi:10.4049/jimmunol.1301152

Milner JJ, Beck MA. 2012. The impact of obesity on the immune response to infection. Proc Nutr Soc 71: 298 306. doi:10.1017/S0029665112000158

Milner JJ, Sheridan PA, Karlsson EA, Schultz-Cherry S, Shi Q, Beck MA. 2013. Diet-induced obese mice exhibit altered heterologous immunity during a secondary 2009 pandemic H1N1 infection. J Immunol 191: 2474-2485. doi:10.4049/jimmunol.1202429

Milner JJ, Rebeles J, Dhungana S, Stewart DA, Sumner SC, Meyers MH, Mancuso P, Beck MA. 2015. Obesity increases mortality and modulates the lung metabolome during pandemic H1N1 influenza virus infection in mice. J Immunol 194: 4846-4859. doi:10.4049/jimmunol.1402295

Moorthy AN, Tan KB, Wang S, Narasaraju T, Chow VT. 2016. Effect of high-fat diet on the formation of pulmonary neutrophil extracellular traps during influenza pneu- monia in BALB/c mice. Front Immunol 7: 289. doi:10 .3389/fimmu.2016.00289

Morens DM, Taubenberger JK, Fauci AS. 2008. Predominant role of bacterial pneumonia as a cause of death in pandemic influenza: implications for pandemic influenza preparedness. J Infect Dis 198: 962-970. doi:10.1086/ 591708

Nachbagauer R, Miller MS, Hai R, Ryder AB, Rose JK, Palese P, García-Sastre A, Krammer F, Albrecht RA. 2016. Hemagglutinin stalk immunity reduces influenza virus replication and transmission in ferrets. J Virol 90: 3268-3273. doi:10.1128/JVI.02481-15

Nair H, Brooks WA, Katz M, Roca A, Berkley JA, Madhi SA, Simmerman JM, Gordon A, Sato M, Howie S, et al. 2011 Global burden of respiratory infections due to seasonal influenza in young children: a systematic review and meta-analysis. Lancet 378: 1917-1930. doi:10.1016/ S0140-6736(11)61051-9

Namkoong H, Ishii M, Fujii H, Asami T, Yagi K, Suzuki S, Azekawa S, Tasaka S, Hasegawa N, Betsuyaku T. 2019. Obesity worsens the outcome of influenza virus infection associated with impaired type I interferon induction in mice. Biochem Biophys Res Commun 513: 405-411. doi:10.1016/j.bbrc.2019.03.211

Neidich SD, Green WD, Rebeles J, Karlsson EA, SchultzCherry S, Noah TL, Chakladar S, Hudgens MG, Weir SS, Beck MA. 2017. Increased risk of influenza among vaccinated adults who are obese. Int J Obey (Lond) 41: 1324-1330. doi:10.1038/ijo.2017.131

Nelson HK, Shi Q, Van Dael P, Schiffrin EJ, Blum S, Barclay D, Levander OA, Beck MA. 2001. Host nutritional selenium status as a driving force for influenza virus mutations. FASEB J 15: 1846-1848. doi:10.1096/fj.01-0115fje

Neuzil KM, Jackson LA, Nelson J, Klimov A, Cox N, Bridges CB, Dunn J, DeStefano F, Shay D. 2006. Immunogenicity and reactogenicity of 1 versus 2 doses of trivalent inactivated influenza vaccine in vaccine-naive 5-8-year-old children. J Infect Dis 194: 1032-1039. doi:10.1086/507309

Nials AT, Uddin S. 2008. Mouse models of allergic asthma: acute and chronic allergen challenge. Dis Model Mech 1: 213-220. doi:10.1242/dmm.000323

Nikolich-Žugich J. 2018. The twilight of immunity: emerging concepts in aging of the immune system. Nat Immunol 19: 10-19. doi:10.1038/s41590-017-0006-x

Norton MT, Fortner KA, Oppenheimer KH, Bonney EA. 2010. Evidence that CD8 T-cell homeostasis and function remain intact during murine pregnancy. Immunology 131: 426-437. doi:10.1111/j.1365-2567.2010.03316.x

Oboho IK, Reed C, Gargiullo P, Leon M, Aragon D, Meek J, Anderson EJ, Ryan P, Lynfield R, Morin C, et al. 2016. Benefit of early initiation of influenza antiviral treatment to pregnant women hospitalized with laboratory-confirmed influenza. J Infect Dis 214: 507-515. doi:10 .1093/infdis/jiw033

O’Brien KB, Vogel P, Duan S, Govorkova EA, Webby RJ, McCullers JA, Schultz-Cherry S. 2012. Impaired wound healing predisposes obese mice to severe influenza virus infection. J Infect Dis 205: 252-261. doi:10.1093/infdis/ jir729

Paquette SG, Banner D, Huang SS, Almansa R, Leon A, Xu L, Bartoszko J, Kelvin DJ, Kelvin AA. 2015. Influenza transmission in the mother-infant dyad leads to severe disease, 
mammary gland infection, and pathogenesis by regulating host responses. PLoS Pathog 11: e1005173. doi:10 .1371/journal.ppat.1005173

Pazos MA, Kraus TA, Muñoz-Fontela C, Moran TM. 2012. Estrogen mediates innate and adaptive immune alterations to influenza infection in pregnant mice. PLoS ONE 7: e40502. doi:10.1371/journal.pone.0040502

Penkert RR, Jones BG, Häcker H, Partridge JF, Hurwitz JL 2017. Vitamin A differentially regulates cytokine expression in respiratory epithelial and macrophage cell lines. Cytokine 91: 1-5. doi:10.1016/j.cyto.2016.11.015

Peretz J, Pekosz A, Lane AP, Klein SL. 2016. Estrogenic compounds reduce influenza A virus replication in primary human nasal epithelial cells derived from female, but not male, donors. Am J Physiol Lung Cell Mol Physiol 310: L415-L425. doi:10.1152/ajplung.00398.2015

Pollett M, Mackenzie JS, Turner KJ. 1979. The effect of protein-deprivation on the susceptibility to influenza virus infection: a murine model system. Aust J Exp Biol Med Sci 57: 151-160. doi:10.1038/icb.1979.16

Potluri T, Fink AL, Sylvia KE, Dhakal S, Vermillion MS Vom Steeg L, Deshpande S, Narasimhan H, Klein SL. 2019. Age-associated changes in the impact of sex steroids on influenza vaccine responses in males and females. NPJ Vaccines 4: 29. doi:10.1038/s41541-019-0124-6

Radigan KA, Morales-Nebreda L, Soberanes S, Nicholson T, Nigdelioglu R, Cho T, Chi M, Hamanaka RB, Misharin AV, Perlman H, et al. 2014. Impaired clearance of influenza A virus in obese, leptin receptor deficient mice is independent of leptin signaling in the lung epithelium and macrophages. PLoS ONE 9: e108138. doi:10.1371/ journal.pone. 0108138

Raj RS, Bonney EA, Phillippe M. 2014. Influenza, immune system, and pregnancy. Reprod Sci 21: 1434-1451. doi:10 $.1177 / 1933719114537720$

Ravanetti L, Dijkhuis A, Sabogal Pineros YS, Bal SM, Dierdorp BS, Dekker T, Logiantara A, Adcock IM, Rao NL, Boon L, et al. 2017. An early innate response underlies severe influenza-induced exacerbations of asthma in a novel steroid-insensitive and anti-IL-5-responsive mouse model. Allergy 72: 737-753. doi:10.1111/all.13057

Rebeles J, Green WD, Alwarawrah Y, Nichols AG, Eisner W, Danzaki K, MacIver NJ, Beck MA. 2019. Obesity-induced changes in T-cell metabolism are associated with impaired memory T-cell response to influenza and are not reversed with weight loss. J Infect Dis 219: 1652-1661. doi:10.1093/infdis/jiy700

Redford PS, Mayer-Barber KD, McNab FW, Stavropoulos E, Wack A, Sher A, O'Garra A. 2014. Influenza A virus impairs control of Mycobacterium tuberculosis coinfection through a type I interferon receptor-dependent pathway. $J$ Infect Dis 209: 270-274. doi:10.1093/infdis/jit424

Renk H, Regamey N, Hartl D. 2014. Influenza A(H1N1) pdm09 and cystic fibrosis lung disease: a systematic meta-analysis. PLoS ONE 9: e78583. doi:10.1371/jour nal.pone.0078583

Reuman PD, Paganini CM, Ayoub EM, Small PA Jr. 1983. Maternal-infant transfer of influenza-specific immunity in the mouse. J Immunol 130: 932-936.

Ring S, Eggers L, Behrends J, Wutkowski A, Schwudke D, Kröger A, Hierweger AM, Hölscher C, Gabriel G, Schneider BE. 2019. Blocking IL-10 receptor signaling ameliorates Mycobacterium tuberculosis infection during influenza-induced exacerbation. JCI Insight 4: e126533. doi:10.1172/jci.insight. 126533

Ritz BW, Aktan I, Nogusa S, Gardner EM. 2008. Energy restriction impairs natural killer cell function and increases the severity of influenza infection in young adult male C57BL/6 mice. J Nutr 138: 2269-2275. doi:10.3945/jn .108 .093633

Roberts S, Salmon SL, Steiner DJ, Williams CM, Metzger DW, Furuya Y. 2019. Allergic airway disease prevents lethal synergy of influenza A virus-Streptococcus pneumoniae coinfection. mBio 10: e01335-19. doi:10.1128/mBio .01335-19

Robinson NP, Venning L, Kyle H, Widdicombe JG. 1986. Quantitation of the secretory cells of the ferret tracheobronchial tree. J Anat 145: 173-188.

Robinson DP, Lorenzo ME, Jian W, Klein SL. 2011. Elevated $17 \beta$-estradiol protects females from influenza A virus pathogenesis by suppressing inflammatory responses. PLoS Pathog 7: e1002149. doi:10.1371/journal.ppat .1002149

Robinson DP, Hall OJ, Nilles TL, Bream JH, Klein SL. 2014 $17 \beta$-estradiol protects females against influenza by recruiting neutrophils and increasing virus-specific CD8 T cell responses in the lungs. J Virol 88: 4711-4720. doi:10.1128/JVI.02081-13

Rosztoczy I, Sweet C, Toms GL, Smith H. 1975. Replication of influenza virus in organ cultures of human and simian urogenital tissues and human foetal tissues. $B r J$ Exp Pathol 56: 322-328.

Ruf BR, Knuf M. 2014. The burden of seasonal and pandemic influenza in infants and children. Eur J Pediatr 173: 265-276. doi:10.1007/s00431-013-2023-6

Samarasinghe AE, Woolard SN, Boyd KL, Hoselton SA, Schuh JM, McCullers JA. 2014. The immune profile associated with acute allergic asthma accelerates clearance of influenza virus. Immunol Cell Biol 92: 449-459. doi:10 $.1038 /$ icb. 2013.113

Samarasinghe AE, Melo RC, Duan S, LeMessurier KS, Liedmann S, Surman SL, Lee JJ, Hurwitz JL, Thomas PG, McCullers JA. 2017. Eosinophils promote antiviral immunity in mice infected with influenza A virus. J Immunol 198: 3214-3226. doi:10.4049/jimmunol.1600787

Samy RP, Lim LH. 2015. DAMPs and influenza virus infection in ageing. Ageing Res Rev 24: 83-97. doi:10.1016/j.arr 2015.07.005

Sansonetti P, Sali M, Fabbiani M, Morandi M, Martucci R, Danesh A, Delogu G, Bermejo-Martin JF, Sanguinetti M, Kelvin D, et al. 2014. Immune response to influenza A (H1N1)v in HIV-infected patients. J Infect Dev Ctries 8: 101-109. doi:10.3855/jidc.3147

Satpathy HK, Lindsay M, Kawwass JF. 2009. Novel H1N1 virus infection and pregnancy. Postgrad Med 121: 106112. doi:10.3810/pgm.2009.11.2080

Sheridan PA, Paich HA, Handy J, Karlsson EA, SchultzCherry S, Hudgens M, Weir S, Noah T, Beck MA. 2015. The antibody response to influenza vaccination is not impaired in type 2 diabetics. Vaccine 33: 3306-3313. doi:10.1016/j.vaccine.2015.05.043

Sheth AN, Althoff KN, Brooks JT. 2011. Influenza susceptibility, severity, and shedding in HIV-infected adults: a 
R. Honce et al.

review of the literature. Clin Infect Dis 52: 219-227. doi:10 .1093/cid/ciq110

Short KR, Kedzierska K, van de Sandt CE. 2018. Back to the future: lessons learned from the 1918 influenza pandemic. Front Cell Infect Microbiol 8: 343. doi:10.3389/fcimb.2018 .00343

Sichelstiel A, Yadava K, Trompette A, Salami O, Iwakura Y, Nicod LP, Marsland BJ. 2014. Targeting IL-1 $\beta$ and IL-17A driven inflammation during influenza-induced exacerbations of chronic lung inflammation. PLoS ONE 9: e98440. doi:10.1371/journal.pone.0098440

Simonsen L, Clarke MJ, Schonberger LB, Arden NH, Cox NJ, Fukuda K. 1998. Pandemic versus epidemic influenza mortality: a pattern of changing age distribution. J Infect Dis 178: 53-60. doi:10.1086/515616

Simpson JL, Scott R, Boyle MJ, Gibson PG. 2006. Inflammatory subtypes in asthma: assessment and identification using induced sputum. Respirology 11: 54-61. doi:10 .1111/j.1440-1843.2006.00784.x

Siston AM, Rasmussen SA, Honein MA, Fry AM, Seib K, Callaghan WM, Louie J, Doyle TJ, Crockett M, Lynfield R, et al. 2010. Pandemic 2009 influenza A(H1N1) virus illness among pregnant women in the United States. J Am Med Assoc 303: 1517-1525. doi:10.1001/jama.2010.479

Smith AG, Sheridan PA, Harp JB, Beck MA. 2007. Dietinduced obese mice have increased mortality and altered immune responses when infected with influenza virus. J Nutr 137: 1236-1243. doi:10.1093/jn/137.5.1236

Soydinc HE, Celen MK, Yıldız B, Sak ME, Evsen MS, Gul T. 2012. Pregnancy and H1N1 infection in southeast Turkey. J Infect Dev Ctries 6: 644-649. doi:10.3855/jidc. 1956

Steinhoff MC, Omer SB, Roy E, Arifeen SE, Raqib R, Altaye M, Breiman RF, Zaman K. 2010. Influenza immunization in pregnancy-antibody responses in mothers and infants. New Engl J Med 362: 1644-1646. doi:10 $.1056 / \mathrm{NEJMc} 0912599$

Stephensen CB, Blount SR, Schoeb TR, Park JY. 1993. Vitamin A deficiency impairs some aspects of the host response to influenza A virus infection in $\mathrm{BALB} / \mathrm{c}$ mice. $J$ Nutr 123: 823-833. doi:10.1093/jn/123.5.823

Strouse JJ, Reller ME, Bundy DG, Amoako M, Cancio M Han RN, Valsamakis A, Casella JF. 2010. Severe pandemic H1N1 and seasonal influenza in children and young adults with sickle cell disease. Blood 116: 3431-3434. doi:10.1182/blood-2010-05-282194

Suber F, Kobzik L. 2017. Childhood tolerance of severe influenza: a mortality analysis in mice. Am J Physiol Lung Cell Mol Physiol 313: L1087-L1095. doi:10.1152/ajplung .00364 .2017

Sun S, Zhao G, Xiao W, Hu J, Guo Y, Yu H, Wu X, Tan Y, Zhou Y. 2011. Age-related sensitivity and pathological differences in infections by 2009 pandemic influenza A (H1N1) virus. Virol J 8: 52. doi:10.1186/1743-422X-8-52

Surman SL, Penkert RR, Jones BG, Sealy RE, Hurwitz JL. 2016. Vitamin supplementation at the time of immunization with a cold-adapted influenza virus vaccine corrects poor mucosal antibody responses in mice deficient for vitamins A and D. Clin Vaccine Immunol 23: 219-227. doi:10.1128/CVI.00739-15

Surman SL, Jones BG, Woodland DL, Hurwitz JL. 2017. Enhanced CD103 expression and reduced frequencies of virus-specific $\mathrm{CD} 8^{+} \mathrm{T}$ cells among airway lymphocytes after influenza vaccination of mice deficient in vitamins A +D. Viral Immunol 30: 737-743. doi:10.1089/vim.2017 .0086

Taglauer ES, Yankee TM, Petroff MG. 2009. Maternal PD-1 regulates accumulation of fetal antigen-specific $\mathrm{CD} 8^{+} \mathrm{T}$ cells in pregnancy. J Reprod Immunol 80: 12-21. doi:10 $.1016 /$ j.jri.2008.12.001

Takeyama T. 1966. Virological studies on experimental infection of pregnant mice with influenza virus. Tohoku J Exp Med 89: 321-340. doi:10.1620/tjem.89.321

Talbot HK. 2017. Influenza in older adults. Infect Dis Clin North Am 31: 757-766. doi:10.1016/j.idc.2017.07.005

Taubenberger JK, Kash JC, Morens DM. 2019. The 1918 influenza pandemic: 100 years of questions answered and unanswered. Sci Transl Med 11: eaau5485. doi:10 $.1126 /$ scitranslmed.aau5485

Taylor AK, Cao W, Vora KP, De La Cruz J, Shieh WJ, Zaki SR, Katz JM, Sambhara S, Gangappa S. 2013. Protein energy malnutrition decreases immunity and increases susceptibility to influenza infection in mice. J Infect Dis 207: 501-510. doi:10.1093/infdis/jis527

Thangavel RR, Bouvier NM. 2014. Animal models for influenza virus pathogenesis, transmission, and immunology. J Immunol Methods 410: 60-79. doi:10.1016/j.jim.2014 .03 .023

Thompson WW, Weintraub E, Dhankhar P, Cheng PY, Brammer L, Meltzer MI, Bresee JS, Shay DK. 2009. Estimates of US influenza-associated deaths made using four different methods. Influenza Other Respir Viruses 3: 3749. doi:10.1111/j.1750-2659.2009.00073.x

Thompson MG, Breiman RF, Hamel MJ, Desai M, Emukule G, Khagayi S, Shay DK, Morales K, Kariuki S, Bigogo GM, et al. 2012. Influenza and malaria coinfection among young children in western Kenya, 2009-2011. J Infect Dis 206: 1674-1684. doi:10.1093/infdis/jis591

Titus P, Jamison JM. 1919. Pregnancy complicated by epidemic influenza. J Am Med Assoc 72: 1665-1668. doi:10 $.1001 /$ jama.1919.02610230019004

Uchide N, Ohyama K, Bessho T, Yuan B, Yamakawa T. 2002. Apoptosis in cultured human fetal membrane cells infected with influenza virus. Biol Pharm Bull 25: 109-114. doi:10.1248/bpb.25.109

Uchide N, Tadera C, Sarai H, Ohyama K, Bessho T, Toyoda H. 2006. Characterization of monocyte differentiationinducing (MDI) factors derived from human fetal membrane chorion cells undergoing apoptosis after influenza virus infection. Int J Biochem Cell Biol 38: 1926-1938. doi:10.1016/j.biocel.2006.05.014

van der Lubbe JEM, Vreugdenhil J, Damman S, Vaneman J, Klap J, Goudsmit J, Radošević K, Roozendaal R. 2017. Maternal antibodies protect offspring from severe influenza infection and do not lead to detectable interference with subsequent offspring immunization. Virol J 14: 123. doi:10.1186/s12985-017-0787-4

Vanders RL, Gibson PG, Murphy VE, Wark PA. 2013. Plasmacytoid dendritic cells and CD8 T cells from pregnant women show altered phenotype and function following H1N1/09 infection. J Infect Dis 208: 1062-1070. doi:10 $.1093 /$ infdis/jit296

Vanders RL, Murphy VE, Gibson PG, Hansbro PM, Wark PA. 2015. CD8 T cells and dendritic cells: key players in the attenuated maternal immune response to influenza 
infection. J Reprod Immunol 107: 1-9. doi:10.1016/j.jri .2014.09.051

Van Kerkhove MD, Vandemaele KA, Shinde V, JaramilloGutierrez G, Koukounari A, Donnelly CA, Carlino LO, Owen R, Paterson B, Pelletier L, et al. 2011. Risk factors for severe outcomes following 2009 influenza A (H1N1) infection: a global pooled analysis. PLoS Med 8: e1001053. doi:10.1371/journal.pmed.1001053

van Riel D, Mittrücker HW, Engels G, Klingel K, Markert UR, Gabriel G. 2016. Influenza pathogenicity during pregnancy in women and animal models. Semin Immunopathol 38: 719-726. doi:10.1007/s00281-016-0580-2

Vermillion MS, Nelson A, Vom Steeg L, Loube J, Mitzner W, Klein SL. 2018a. Pregnancy preserves pulmonary function following influenza virus infection in C57BL/6 mice. Am J Physiol Lung Cell Mol Physiol 315: L517-L525. doi:10.1152/ajplung.00066.2018

Vermillion MS, Ursin RL, Attreed SE, Klein SL. 2018b. Estriol reduces pulmonary immune cell recruitment and inflammation to protect female mice from severe influenza. Endocrinology 159: 3306-3320. doi:10.1210/en.201800486

Vermillion MS, Ursin RL, Kuok DIT, Vom Steeg LG, Wohlgemuth N, Hall OJ, Fink AL, Sasse E, Nelson A, Ndeh R, et al. 2018c. Production of amphiregulin and recovery from influenza is greater in males than females. Biol Sex Differ 9: 24. doi:10.1186/s13293-018-0184-8

Viboud C, Eisenstein J, Reid AH, Janczewski TA, Morens DM, Taubenberger JK. 2013. Age- and sex-specific mortality associated with the 1918-1919 influenza pandemic in Kentucky. J Infect Dis 207: 721-729. doi:10.1093/in fdis/jis 745

Vijayan VK. 2013. Chronic obstructive pulmonary disease. Indian J Med Res 137: 251-269.

Vom Steeg LG, Klein SL. 2017. Sex steroids mediate bidirectional interactions between hosts and microbes. Horm Behav 88: 45-51. doi:10.1016/j.yhbeh.2016.10.016

Vom Steeg LG, Klein SL. 2019. Sex and sex steroids impact influenza pathogenesis across the life course. Semin Immunopathol 41: 189-194. doi:10.1007/s00281-0180718-5

Vom Steeg LG, Vermillion MS, Hall OJ, Alam O, McFarland R, Chen H, Zirkin B, Klein SL. 2016. Age and testosterone mediate influenza pathogenesis in male mice. Am J Physiol Lung Cell Mol Physiol 311: L1234-L1244. doi:10.1152/ ajplung.00352.2016

Walaza S, Tempia S, Dawood H, Variava E, Moyes J, Cohen AL, Wolter N, Groome M, von Mollendorf C, Kahn K, et al. 2015. Influenza virus infection is associated with increased risk of death amongst patients hospitalized with confirmed pulmonary tuberculosis in South Africa, 2010-2011. BMC Infect Dis 15: 26. doi:10.1186/s12879015-0746-X

Walters KA, D'Agnillo F, Sheng ZM, Kindrachuk J, Schwartzman LM, Kuestner RE, Chertow DS, Golding BT, Taubenberger JK, Kash JC. 2016. 1918 pandemic influenza virus and Streptococcus pneumoniae co-infection results in activation of coagulation and widespread pulmonary thrombosis in mice and humans. J Pathol 238: 85-97. doi:10.1002/path.4638

Wang J, Li Q, Xie J, Xu Y. 2015. Cigarette smoke inhibits BAFF expression and mucosal immunoglobulin A re- sponses in the lung during influenza virus infection. Respir Res 16: 37. doi:10.1186/s12931-015-0201-y

Williams K, Mackenzie JS. 1977. Influenza infections during pregnancy in the mouse. J Hyg (Lond) 79:249-257. doi:10 $.1017 /$ S0022172400053067

Wolk KE, Lazarowski ER, Traylor ZP, Yu EN, Jewell NA, Durbin RK, Durbin JE, Davis IC. 2008. Influenza A virus inhibits alveolar fluid clearance in BALB/c mice. Am J Respir Crit Care Med 178: 969-976. doi:10.1164/rccm .200803-455OC

Wong CK, Smith CA, Sakamoto K, Kaminski N, Koff JL, Goldstein DR. 2017. Aging impairs alveolar macrophage phagocytosis and increases influenza-induced mortality in mice. J Immunol 199: 1060-1068. doi:10.4049/jimmu nol.1700397

Woods PS, Tazi MF, Chesarino NM, Amer AO, Davis IC. 2015. TGF- $\beta$-induced IL- 6 prevents development of acute lung injury in influenza A virus-infected F508del CFTRheterozygous mice. Am J Physiol Lung Cell Mol Physiol 308: L1136-L1144. doi:10.1152/ajplung.00078.2015

Woolston WJ, Conley DO. 1918. Epidemic pneumonia (Spanish influenza) in pregnancy: effect in one hundred and one cases. J Am Med Assoc 71: 1898-1899. doi:10 .1001/jama.1918.02600490030008

World Health Organization WHO. 2018. Influenza (Seasonal). WHO.

Wortham BW, Eppert BL, Motz GT, Flury JL, Orozco-Levi M, Hoebe K, Panos RJ, Maxfield M, Glasser SW, Senft AP, et al. 2012. NKG2D mediates NK cell hyperresponsiveness and influenza-induced pathologies in a mouse model of chronic obstructive pulmonary disease. J Immunol 188: 4468-4475. doi:10.4049/jimmunol.1102643

Wu J, Zhang F, Fang F, Chang H, Wang F, Yang Z, Sun B, Chen Z. 2010. Efficacy of inactivated vaccine against $\mathrm{H} 5 \mathrm{~N} 1$ influenza virus infection in mice with type 1 diabetes. Vaccine 28: 2775-2781. doi:10.1016/j.vaccine.2010 .01 .037

Wu W, Zhang W, Booth JL, Hutchings DC, Wang X, White VL, Youness H, Cross CD, Zou MH, Burian D, et al. 2016. Human primary airway epithelial cells isolated from active smokers have epigenetically impaired antiviral responses. Respir Res 17: 111. doi:10.1186/s12931-0160428-2

Xu W, Zheng S, Goggans TM, Kiser P, Quinones-Mateu ME, Janocha AJ, Comhair SA, Slee R, Williams BR, Erzurum SC. 2006. Cystic fibrosis and normal human airway epithelial cell response to influenza a viral infection. J Interferon Cytokine Res 26: 609-627. doi:10.1089/jir.2006.26 .609

Xu L, Bao L, Deng W, Qin C. 2011. Highly pathogenic avian influenza $\mathrm{H} 5 \mathrm{~N} 1$ virus could partly be evacuated by pregnant $\mathrm{BALB} / \mathrm{c}$ mouse during abortion or preterm delivery. Virol J 8: 342. doi:10.1186/1743-422X-8-342

Yager EJ, Ahmed M, Lanzer K, Randall TD, Woodland DL, Blackman MA. 2008. Age-associated decline in T cell repertoire diversity leads to holes in the repertoire and impaired immunity to influenza virus. J Exp Med 205: 711-723. doi:10.1084/jem.20071140

Yam KK, Gupta J, Allen EK, Burt KR, Beaulieu E, Mallett CP Burt DS, Ward BJ. 2016. Comparison of AS03 and Alum on immune responses elicited by A/H3N2 split influenza 


\section{R. Honce et al.}

vaccine in young, mature and aged $\mathrm{BALB} / \mathrm{c}$ mice. Vaccine 34: 1444-1451. doi:10.1016/j.vaccine.2016.02.012

Yasui H, Kiyoshima J, Hori T. 2004. Reduction of influenza virus titer and protection against influenza virus infection in infant mice fed Lactobacillus casei Shirota. Clin Diagn Lab Immunol 11: 675-679.

Yoon SW, Wong SS, Zhu H, Chen R, Li L, Zhang Y, Guan Y, Webby RJ. 2018. Dysregulated T-helper type 1 (Th1):Th2 cytokine profile and poor immune response in pregnant ferrets infected with 2009 pandemic influenza $\mathrm{A}(\mathrm{H} 1 \mathrm{N1})$ virus. J Infect Dis 217: 438-442. doi:10.1093/infdis/jix328

Zeeni N, Dagher-Hamalian C, Dimassi H, Faour WH. 2015. Cafeteria diet-fed mice is a pertinent model of obesity-induced organ damage: a potential role of inflammation. Inflamm Res 64: 501-512. doi:10.1007/ s00011-015-0831-z

Zerbo O, Modaressi S, Chan B, Goddard K, Lewis N, Bok K, Fireman B, Klein NP, Baxter R. 2017. No association between influenza vaccination during pregnancy and adverse birth outcomes. Vaccine 35: 3186-3190. doi:10 $.1016 /$ j.vaccine. 2017.04 .074

Zhang AJ, To KK, Li C, Lau CC, Poon VK, Chan CC, Zheng BJ, Hung IF, Lam KS, Xu A, et al. 2013. Leptin mediates the pathogenesis of severe 2009 pandemic influenza A (H1N1) infection associated with cytokine dysregulation in mice with diet-induced obesity. J Infect Dis 207: 12701280. doi:10.1093/infdis/jit031
Zhang Y, Aevermann BD, Anderson TK, Burke DF, Dauphin G, Gu Z, He S, Kumar S, Larsen CN, Lee AJ, et al. 2017. Influenza research database: an integrated bioinformatics resource for influenza virus research. Nucleic Acids Res 45: D466-D474. doi:10.1093/nar/gkw857

Zhang A, Stacey HD, Mullarkey CE, Miller MS. 2019a. Original antigenic sin: how first exposure shapes lifelong antiinfluenza virus immune responses. J Immunol 202: 335340. doi:10.4049/jimmunol.1801149

Zhang AJX, Zhu H, Chen Y, Li C, Li C, Chu H, Gozali L, Lee ACY, To KKW, Hung IFN, et al. 2019b. Prostaglandin $E_{2}-$ mediated impairment of innate immune response to $\mathrm{A}$ (H1N1)pdm09 infection in diet-induced obese mice could be restored by paracetamol. J Infect Dis 219: 795807. doi:10.1093/infdis/jiy527

Zheng R, Qin X, Li Y, Yu X, Wang J, Tan M, Yang Z, Li W. 2012. Imbalanced anti-H1N1 immunoglobulin subclasses and dysregulated cytokines in hospitalized pregnant women with $2009 \mathrm{H} 1 \mathrm{~N} 1$ influenza and pneumonia in Shenyang, China. Hum Immunol 73: 906-911. doi:10 .1016/j.humimm.2012.06.005

Zhu Q, Chang H, Chen Y, Fang F, Xue C, Zhang F, Qiu M, Wang H, Wang B, Chen Z. 2005. Protection of inactivated influenza virus vaccine against lethal influenza virus infection in diabetic mice. Biochem Biophys Res Commun 329: 87-94. doi:10.1016/j.bbrc.2005.01.109 


\section{$\&_{\mathrm{CSH}}^{\infty} \&$ Cold Spring Harbor

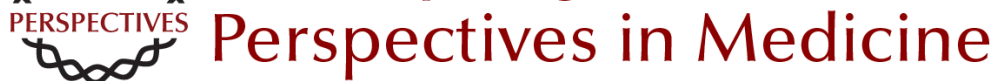

\section{Influenza in High-Risk Hosts--Lessons Learned from Animal Models}

Rebekah Honce, Nicholas Wohlgemuth, Victoria A. Meliopoulos, Kirsty R. Short and Stacey

Schultz-Cherry

Cold Spring Harb Perspect Med 2020; doi: 10.1101/cshperspect.a038604 originally published online December 23, 2019

Subject Collection Influenza: The Cutting Edge

Emerging HxNy Influenza A Viruses

William J. Liu, Yan Wu, Yuhai Bi, et al.

Equine Influenza

Thomas M. Chambers

Human Influenza Epidemiology Sukhyun Ryu and Benjamin J. Cowling

Host Cell Factors That Interact with Influenza Virus Ribonucleoproteins

Ecco Staller and Wendy S. Barclay

Induction and Evasion of Type-I Interferon

Responses during Influenza A Virus Infection Raquel Muñoz-Moreno, Carles Martínez-Romero and Adolfo García-Sastre

Structure and Function of Influenza Polymerase Joanna M. Wandzik, Tomas Kouba and Stephen Cusack

H7N9 Influenza Virus in China Chengjun Li and Hualan Chen

H5 Influenza Viruses in Egypt Rabeh El-Shesheny, Ahmed Kandeil, Ahmed Mostafa, et al.
Antivirals Targeting the Neuraminidase

Larisa Gubareva and Teena Mohan

Accessory Gene Products of Influenza A Virus Rute M. Pinto, Samantha Lycett, Eleanor Gaunt, et al.

Influenza Immunization in the Context of

Preexisting Immunity Susanne L. Linderman, Ali H. Ellebedy, Carl Davis, et al.

Hemagglutinin Structure and Activities Steven J. Gamblin, Sébastien G. Vachieri, Xiaoli Xiong, et al.

Live Attenuated Cold-Adapted Influenza Vaccines Kanta Subbarao

Next-Generation Influenza Vaccines Masaru Kanekiyo and Barney S. Graham

\section{Selective Genome Packaging Mechanisms of Influenza A Viruses \\ Takeshi Noda}

Systems Biological Analysis of Immune Response

to Influenza Vaccination Mario Cortese, Amy C. Sherman, Nadine G. Rouphael, et al.

For additional articles in this collection, see http://perspectivesinmedicine.cshlp.org/cgi/collection/ 